\title{
New Phenoxyl Radical Complexes of Manganese, Gallium, Indium and Iron Based on an $\mathrm{H}_{2}$ bbpen Ligand Derivative
}

\author{
Ademir dos Anjos, ${ }^{a}$ Adailton J. Bortoluzzi, ${ }^{a}$ Miguel S. B. Caro, ${ }^{a}$ Rosely A. Peralta, \\ Geraldo R. Friedermann, Antonio S. Mangrich ${ }^{b}$ and Ademir Neves ${ }^{*, a}$ \\ ${ }^{a}$ LABINC, Departamento de Química, Universidade Federal de Santa Catarina, \\ 88040-900 Florianópolis-SC, Brazil \\ ${ }^{b}$ LABEPR, Departamento de Química, Universidade Federal do Paraná, \\ 81531-970 Curitiba-PR, Brazil
}

\begin{abstract}
Reportamos aqui a síntese e caracterização do ligante hexadentado $\mathrm{H}_{2} \mathrm{~L}\left(N, N^{\prime}, N, N^{\prime}\right.$-bis[(2hidroxi-3,5-di-terc-butilbenzil)(2-piridilmetil)] etilenodiamino), como derivado adicional do bem conhecido pré-ligante $\mathrm{H}_{2}$ bbpen, e que contém dois grupos fenolatos e dois grupos piridínicos conectados à unidade etilenodiamina. Os grupos fenolatos no pré-ligante $\mathrm{H}_{2} \mathrm{~L}$ estão adequadamente protegidos por grupos substituintes volumosos (terc-butil) nas posições orto- e para-, a partir dos quais complexos contendo radicais fenoxil estáveis podem ser obtidos. Assim, sintetizamos quatro novos complexos mononucleares com $\mathrm{Mn}^{\mathrm{III}}, \mathrm{Ga}^{\mathrm{III}}, \mathrm{In}^{\mathrm{III}}$ e $\mathrm{Fe}^{\mathrm{III}}$, que através de oxidação eletroquímica produzem espécies fenoxil mono- ou di-oxidadas em solução. Estas espécies radicalares foram caracterizadas por espectroscopia UV-Vis e Ressonância Paramagnética Eletrônica e estudos eletroquímicos. Como esperado, no caso dos complexos de $\mathrm{Ga}^{\mathrm{III}}, \mathrm{In}^{\mathrm{III}}$ e $\mathrm{Fe}^{\mathrm{III}}$, nenhum processo de oxidação centrado no metal foi observado. Entretanto, o complexo de manganês sofre processos de oxidação centrados tanto no metal quanto no ligante e conseqüentemente um complexo $\mathrm{Mn}^{\mathrm{IV}}-$ radical fenoxil pode ser gerado em solução. As estruturas dos complexos $\left[\mathrm{Mn}^{\mathrm{III}}(\mathrm{L})\right]^{+}$e $\left[\mathrm{Ga} \mathrm{aII}^{\mathrm{II}}(\mathrm{L})\right]^{+}$ foram determinadas por análises de cristalografia de raios $\mathrm{X}$, revelando complexos monocatiônicos com geometrias octaédricas distorcidas.
\end{abstract}

Reported herein are the synthesis and characterization of the hexadentate $\mathrm{H}_{2} \mathrm{~L}$ pro-ligand $\left(N, N^{\prime}, N, N^{\prime}\right.$-bis[(2-hydroxy-3,5-di-tert-butylbenzyl)(2-pyridylmethyl)]ethylenediamine), as a further derivative of the well known pro-ligand $\mathrm{H}_{2}$ bbpen which contains two phenolate and two pyridyl pendant arms. The phenolate groups in $\mathrm{H}_{2} \mathrm{~L}$ are suitably protected by bulky substituents (tert-butyl) in the ortho- and para- positions, from which stable phenoxyl radical complexes can be formed. Thus, we have synthesized four new mononuclear complexes with $\mathrm{Mn}^{\mathrm{III}}, \mathrm{Ga}^{\mathrm{III}}$, $\mathrm{In}^{\mathrm{III}}$ and $\mathrm{Fe}^{\mathrm{III}}$ which through electrochemical oxidation generate one- and two-electron oxidized phenoxyl species in solution. These radical species were characterized by UV-Vis, Electronic Paramagnetic Resonance and electrochemical studies. As expected, in the case of the Ga ${ }^{\text {III }}, \mathrm{In}^{\text {III }}$ and $\mathrm{Fe}^{\mathrm{III}}$ complexes no metal-centered oxidation was observed. However, the manganese complex undergoes metal- and ligand-centered oxidation processes and therefore a phenoxyl radical$\mathrm{Mn}^{\mathrm{IV}}$ complex can be generated in solution. The crystal structures of the $\left[\mathrm{Mn} n^{\mathrm{III}}(\mathrm{L})\right]^{+}$and $\left[\mathrm{Ga}{ }^{\mathrm{III}}(\mathrm{L})\right]^{+}$ complexes were determined by X-ray crystallographic analyses revealing monocationic complexes with distorted octahedral geometries.

Keywords: $\mathrm{H}_{2}$ bbpen, trivalent complexes, phenoxyl radical, crystal structures

\section{Introduction}

Extensive efforts have been made to provide valuable insight into the general aspects of the structures, physicochemical properties, and functions

*e-mail: ademir@qmc.ufsc.br of phenoxyl radical complexes with a series of transition-metal ions. ${ }^{1-5}$ In an attempt to understand the spectroscopic properties, redox features, stability and chemical reactivity of phenoxyl radicals a series of recent model studies using $\mathrm{M}^{\mathrm{III}}$-phenoxyl radical complexes $(\mathrm{M}=\mathrm{Ga}, \mathrm{Fe}, \mathrm{Mn}, \mathrm{Cr}, \mathrm{Sc}$ and $\mathrm{Co})$ has been reported by Wieghardt and co-workers ${ }^{1,6-10}$ 
Ligands based on the salen [ $N, N^{\prime}$-alkyl-bis (-salicylimine)] frame have been the most extensively studied, since they are known to be of general utility in transition metal chemistry. ${ }^{2}$ In particular, complexes which have many applications have been prepared utilizing substituted and unsubstituted $\mathrm{H}_{2}$ bbpen proligands $\left(\mathrm{H}_{2}\right.$ bbpen $=\left\{N, N^{\prime}, N, N^{\prime}\right.$-bis $[(2$-hydroxybenzyl $)(2$ pyridylmethyl)] ethylenediamine $\}) .{ }^{11-16}$ Manganese ${ }^{11,12}$ and vanadium ${ }^{13-15}$ complexes with bbpen ${ }^{2-}$ have been reported as interesting structural models for manganese and vanadium-containing metalloenzymes while those of gallium and indium have been reported as being of interest in nuclear medicine applications. ${ }^{16}$

In this paper we present the new $\mathrm{H}_{2}$ bbpen derivative pro-ligand $\mathrm{H}_{2} \mathrm{~L}$, which contains two phenolate pendant arms with bulky substituents (tert-butyl) in the ortho- and para- positions, which enable it to produce stable phenoxyl radical complexes. The mononuclear cation complexes (schematic representation shown in chart 1) $\left[\mathrm{M}^{\mathrm{III}}(\mathrm{L})\right]^{+}(\mathrm{M}$ $=\mathrm{Mn}, \mathrm{Ga}, \mathrm{In}$ and $\mathrm{Fe}$ ), were easily obtained through stoichiometric reactions of $\mathrm{H}_{2} \mathrm{~L}$ and the hydrated metal salts of $\mathrm{Mn}, \mathrm{Ga}$, In and $\mathrm{Fe}$ in methanolic solutions. Electrochemical oxidation of the $\left[\mathrm{M}^{\mathrm{III}}(\mathrm{L})\right]^{+}$complexes generates one- and two-electron oxidized phenoxyl species in solution which were characterized by UV-Vis, EPR and electrochemical studies. The crystal structures of the $\left[\mathrm{Mn}^{\mathrm{III}}(\mathrm{L})\right]^{+}$and $\left[\mathrm{Ga}^{\mathrm{III}}(\mathrm{L})\right]^{+}$complexes were determined by $\mathrm{X}$-ray crystallographic analysis revealing monocationic complexes with distorted octahedral geometries.

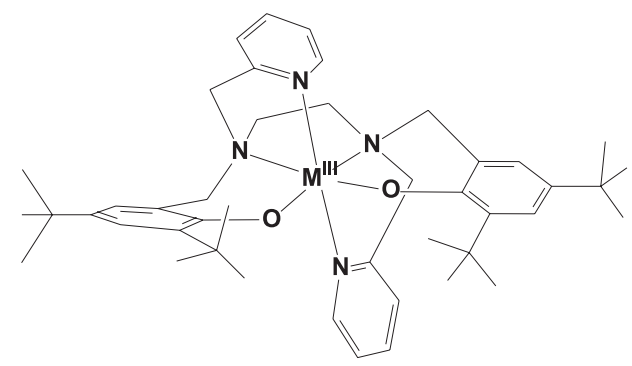

Scheme 1. Schematic representation of the $\left[\mathrm{M}^{\mathrm{III}}(\mathrm{L})\right]^{+}$cations $(\mathrm{M}=\mathrm{Mn}$, $\mathrm{Ga}$, In, or $\mathrm{Fe}$ ).

\section{Experimental}

\section{Abbreviations}

$\mathrm{H}_{2}$ bbpen: $\left\{N, N^{\prime}, N, N^{\prime}\right.$-bis [(2-hydroxylbenzyl $)(2-$ pyridylmethyl)] ethylenediamine $\} ; \mathrm{H}_{2} \mathrm{~L}:\left\{N, N^{\prime}, N, N^{\prime}-\right.$ bis[(2-hydroxy-3,5-di-t-butylbenzyl)(2-pyridylmethyl)] ethylenediamine ; [TBA] $\left[\mathrm{PF}_{6}\right]$ : tetra-n-butylammonium hexafluorophosphate; SWV: square wave voltammetry; CV: cyclic voltammetry.
Materials

2-pyridinecarboxaldehyde, $\mathrm{Mn}\left(\mathrm{ClO}_{4}\right)_{2} \cdot 6 \mathrm{H}_{2} \mathrm{O}$, $\mathrm{Ga}\left(\mathrm{NO}_{3}\right)_{3} \cdot \mathrm{H}_{2} \mathrm{O}, \mathrm{In}\left(\mathrm{NO}_{3}\right)_{3} \cdot \mathrm{H}_{2} \mathrm{O}, \mathrm{Fe}\left(\mathrm{ClO}_{4}\right)_{3} \cdot 9 \mathrm{H}_{2} \mathrm{O}$ and tetra$n$-butylammonium hexafluorophosphate $[\mathrm{TBA}]\left[\mathrm{PF}_{6}\right]$ were obtained from Aldrich Chemical Co. 3,5-di-tert-butyl-2hydroxybenzyl chloride was synthesized through the modification of a method described in the literature. ${ }^{17}$ Triethylamine $\left(\mathrm{Et}_{3} \mathrm{~N}\right)$ and ethylenediamine were obtained from Merck. The reagents and solvents used in the syntheses were reagent grade and used without further purification. Spectroscopic grade solvents from Merck were dried on molecular sieves for physicochemical characterization of the complexes. High-purity argon was used to deoxygenate solutions.

\section{Physical measurements}

Elemental analyses were performed with a Perkin-Elmer 2400 instrument. IR spectra were measured in the range 4000$400 \mathrm{~cm}^{-1}$ with $\mathrm{KBr}$ pellets, using a Perkin-Elmer 781 spectrometer. The solution electrical conductivity was measured with a Digimed conductivity bridge, Type CD-21, with solute concentrations of $c a \cdot 10^{-3} \mathrm{~mol} \mathrm{dm}^{-3}$. The NMR spectra were obtained on a Bruker-FT $200 \mathrm{MHz}\left({ }^{1} \mathrm{H},{ }^{1} \mathrm{H}-{ }^{1} \mathrm{H}\right.$ $\mathrm{COSY}$ ) spectrometer in $\mathrm{CD}_{3} \mathrm{CN}$ (complexes $\mathbf{2}$ and $\mathbf{3}$ ), at 25 ${ }^{\circ} \mathrm{C}$. Chemical shifts were referenced to tetramethylsilane (TMS). Electronic and spectroelectrochemical spectra of the complexes were recorded on a Perkin-Elmer Lambda-19 spectrophotometer and Varian Cary 50Bio. First derivative EPR spectroscopy of "powdered" and solution samples was carried out with a Bruker ESP 300E X-band spectrometer. Cyclic voltammetry, square-wave voltammetry and coulometry were carried out with a Princeton Applied Research (PARC) model 273 potentiostat/galvanostat in dichloromethane solutions containing $0.1 \mathrm{~mol} \mathrm{dm}^{-3}$ $[\mathrm{TBA}]\left[\mathrm{PF}_{6}\right]$ as the supporting electrolyte (argon atmosphere, room temperature and $-60{ }^{\circ} \mathrm{C}$ ) in a conventional electrochemical cell. Glassy carbon and platinum wire electrodes were used as the working and counter electrodes, respectively. Potentials were referenced to the $\mathrm{Ag} / \mathrm{Ag}^{+}$electrode constructed in our laboratory. The $\mathrm{Fc}^{+} / \mathrm{Fc}$ couple $\left(E^{\circ}=400\right.$ $\mathrm{mV} v$ s. NHE) was used as an internal standard ${ }^{18}$ to monitor the reference electrode and was observed at $+385 \mathrm{mV}$ versus $\mathrm{Ag} / \mathrm{Ag}^{+}$.

\section{Synthesis}

$H_{2} L$. This compound was prepared by the reaction between ethylenediamine and 2-pyridinecarboxaldehyde followed by reduction with $\mathrm{NaBH}_{4}$ and addition of 3,5-di-tert-butyl- 
2-hydroxybenzyl chloride as reported in the literature. ${ }^{19}$ mp 134-135 ${ }^{\circ} \mathrm{C} .{ }^{19}{ }^{1} \mathrm{H}$ NMR $\left(200 \mathrm{MHz}\right.$; solvent $\mathrm{CDCl}_{3}$; standard $\left.\mathrm{SiMe}_{4}\right) \delta: 8.51\left(2 \mathrm{H}_{6}, \mathrm{~d},{ }^{3} \mathrm{~J}_{\mathrm{H} 6 / \mathrm{H} 5} 4.6 \mathrm{~Hz}\right), 7.58\left(2 \mathrm{H}_{4}\right.$, $\left.\mathrm{dd},{ }^{3} J_{\mathrm{H} 4 / \mathrm{H} 5} 7.6 \mathrm{~Hz},{ }^{3} J_{\mathrm{H} 4 / \mathrm{H} 3} 7.6 \mathrm{~Hz}\right), 7.26-7.19\left(2 \mathrm{H}_{5}, 2 \mathrm{H}_{3}\right.$, $\left.2 \mathrm{H}_{8}, \mathrm{~m}\right), 6.83\left(2 \mathrm{H}_{7}, \mathrm{~s}\right), 3.76\left(4 \mathrm{H}_{2}, 4 \mathrm{H}_{2}, \mathrm{~s}\right), 2.88\left(2 \mathrm{H}_{1}, 2 \mathrm{H}_{1}\right.$, s), $1.38\left(18 \mathrm{H}_{9}, \mathrm{~s}\right), 1.25\left(18 \mathrm{H}_{10}, \mathrm{~s}\right)$; the phenolic protons were observed at $10.5 \mathrm{ppm} .{ }^{13} \mathrm{C}$ NMR $(200 \mathrm{MHz}$; solvent $\mathrm{CDCl}_{3}$; standard $\left.\mathrm{SiMe}_{4}\right) \delta: 157.4\left(\mathrm{C}_{4}\right), 153.8\left(\mathrm{C}_{14}\right), 149.0$ $\left(\mathrm{C}_{8}\right), 140.5\left(\mathrm{C}_{11}\right), 136.4\left(\mathrm{C}_{6}\right), 135.6\left(\mathrm{C}_{13}\right), 123.8\left(\mathrm{C}_{5}\right), 123.6$ $\left(\mathrm{C}_{10}\right), 122.9\left(\mathrm{C}_{7}\right), 122.2\left(\mathrm{C}_{12}\right), 121.2\left(\mathrm{C}_{9}\right), 59.4\left(\mathrm{C}_{3}\right), 59.0$ $\left(\mathrm{C}_{2}\right), 50.5\left(\mathrm{C}_{1}\right), 34.8\left(\mathrm{C}_{15}\right), 34.0\left(\mathrm{C}_{16}\right), 31.6\left(\mathrm{C}_{17}\right), 29.6\left(\mathrm{C}_{18}\right)$. Caution! the complex isolated as the perchlorate salt should be handled as a potentially explosive compound.

$\left[\mathrm{Mn} n^{I I I}(\mathrm{~L})\right]\left(\mathrm{ClO}_{4}\right) \cdot 1 / 2 \mathrm{H}_{2} \mathrm{O}(\mathrm{1})$. The reaction of $\mathrm{Mn}\left(\mathrm{ClO}_{4}\right)_{2}$. $6 \mathrm{H}_{2} \mathrm{O}(0.362 \mathrm{~g}, 1.0 \mathrm{mmol})$ with $\mathrm{H}_{2} \mathrm{~L}(0.679 \mathrm{~g}, 1.0 \mathrm{mmol})$ in methanol afforded a purple microcrystalline precipitate which was filtered off, washed with cold methanol and ether, and dried under vacuum. Yield: $89 \%$. Single violet crystals of the complex suitable for X-ray crystallography were obtained by recrystallization from an ethanol/acetone (1:1) solution of 1. Anal. Calc. for $\mathrm{MnC}_{44} \mathrm{H}_{61} \mathrm{~N}_{4} \mathrm{O}_{6.5} \mathrm{Cl}$ (MW: 840.36 $\mathrm{g} \mathrm{mol}^{-1}$ ): C, 62.89; H, 7.32; N, 6.67\%. Found: C, 62.81; H, $7.52 ; \mathrm{N}, 6.74 \%$. IR (KBr) $v_{\max } / \mathrm{cm}^{-1}: v$ (CH $t$-butyl) 2951vs; $v(\mathrm{CO}) 1243 \mathrm{~s} ; \mathrm{v}(\mathrm{ClO})$ 1093vs.

$\left[\mathrm{Ga}^{I I I}(\mathrm{~L})\right]\left(\mathrm{ClO}_{4}\right) \cdot \mathrm{CH}_{3} \mathrm{OH} \cdot 2 \mathrm{H}_{2} \mathrm{O}(2)$. The pro-ligand $\mathrm{H}_{2} \mathrm{~L}$ $(0.679 \mathrm{~g}, 1.0 \mathrm{mmol})$ reacts in methanol with $\mathrm{Ga}\left(\mathrm{NO}_{3}\right)_{3}$ $(0.256 \mathrm{~g}, 1.0 \mathrm{mmol})$ and $\mathrm{NaClO}_{4}(0.122 \mathrm{~g}, 1.0 \mathrm{mmol})$ to form a stable white microcrystalline precipitate. The complex was filtered off, washed with cold methanol and dried under vacuum. Yield: $75 \%$. Crystals suitable for $\mathrm{X}$-ray crystallography were obtained by recrystallization from a methanolic solution of 2. Anal. Calc. for $\mathrm{GaC}_{44} \mathrm{H}_{62} \mathrm{~N}_{4} \mathrm{O}$ Cl (MW: $864.17 \mathrm{~g} \mathrm{~mol}^{-1}$ ): C, 61.15; H, 7.23; $\mathrm{N}, 6.48 \%$. Found: C, 61.30; H, 7.03; N, 6.57\%. IR (KBr) $v_{\max } / \mathrm{cm}^{-1}: v(\mathrm{CH} t$-butyl) 2949vs; v(CO) 1260s; v (ClO) 1096vs.

$\left[\operatorname{In}^{I I I}(\mathrm{~L})\right]\left(\mathrm{ClO}_{4}\right) \cdot \mathrm{H}_{2} \mathrm{O}(3)$. The $\operatorname{In}\left(\mathrm{NO}_{3}\right)_{3} \cdot \mathrm{H}_{2} \mathrm{O}(0.355 \mathrm{~g}, 1.0$ mmol) reacts in methanol with $\mathrm{H}_{2} \mathrm{~L}(0.679 \mathrm{~g}, 1.0 \mathrm{mmol})$ in the presence of $\mathrm{NaClO}_{4}(0.122 \mathrm{~g}, 1.0 \mathrm{mmol})$ to form a stable white microcrystalline complex which was filtered off, washed with cold methanol and dried under vacuum. Yield: 71\%. Anal. Calc. for $\mathrm{InC}_{44} \mathrm{H}_{62} \mathrm{~N}_{4} \mathrm{O}_{7} \mathrm{Cl}$ (MW:909.27g $\left.\mathrm{mol}^{-1}\right)$ : C, 58.12; H, 6.87; N, 6.16\%. Found: C, 58.72; H, $6.89 ; \mathrm{N}, 6.10 \%$. IR (KBr) $v_{\max } / \mathrm{cm}^{-1}: v(\mathrm{CH} t$-butyl) $2953 \mathrm{vs}$; $v(\mathrm{CO}) 1268 \mathrm{~s} ; \mathrm{v}(\mathrm{ClO}) 1093 \mathrm{vs}$.

$\left[\mathrm{Fe}^{I I I}(\mathrm{~L})\right]\left(\mathrm{ClO}_{4}\right) \cdot \mathrm{H}_{2} \mathrm{O}(4)$. A mixture of $\mathrm{Fe}\left(\mathrm{ClO}_{4}\right)_{3} \cdot 9 \mathrm{H}_{2} \mathrm{O}$ $(0.516 \mathrm{~g}, 1.0 \mathrm{mmol})$ and $\mathrm{H}_{2} \mathrm{~L}(0.679 \mathrm{~g}, 1.0 \mathrm{mmol})$ in methanol afforded a blue microcrystalline precipitate which was filtered off, washed with cold methanol and ether, and dried under vacuum. Yield: $85 \%$. Anal. Calc. for $\mathrm{FeC}_{44} \mathrm{H}_{62} \mathrm{~N}_{4} \mathrm{O}_{7} \mathrm{Cl}\left(\mathrm{MW}: 850.30 \mathrm{~g} \mathrm{~mol}^{-1}\right.$ ): C, 62.15; $\mathrm{H}$, 7.35 ; N, 6.59\%. Found: C, 61.75; H, 7.14; N, 6.51\%. IR (KBr) $v_{\max } / \mathrm{cm}^{-1}: v(\mathrm{CH} t$-butyl) 2953vs; v(CO) 1268s; v (ClO) 1091 vs.

Determination of the crystal structures of complexes $\mathbf{1}$ and 2

For both complexes, the intensity data were collected with an Enraf-Nonius CAD4 diffractometer, at room temperature, with graphite-monochromated $\mathrm{MoK} \alpha$ radiation. Cell parameters were determined from 25 carefully centered reflections using a standard procedure..$^{20}$ All data were corrected for Lorentz and polarization effects. ${ }^{21}$ An empirical absorption correction based on the azimuthal scans of 7 appropriate reflections was also applied to the collected intensities with the PLATON program $^{22}\left(\mathrm{~T}_{\min }=0.811 ; \mathrm{T}_{\max }=0.891\right)$. The structure was solved by direct methods and refined by full-matrix leastsquares methods using SIR $97^{23}$ and SHELXL9724 programs, respectively.

Complex 1. A dark green crystal was selected from the crystalline sample of complex 1 under polarized light and fixed at the end of a glass fiber for X-ray analysis. Most of the non-hydrogen atoms were refined anisotropically, the exceptions being for some carbon atoms of tert-butyl fragments and the oxygen atoms of the perchlorate couterions. $\mathrm{H}$ atoms attached to $\mathrm{C}$ atoms were placed at their idealized positions, with C-H distances and $U_{\text {eq }}$ values taken from the default settings of the refinement program. The $\mathrm{H}$ atoms of the water molecule of crystallization were not found on the Fourier difference map. One perchlorate group was found to be disordered. In the case of this perchlorate (Cl1) three oxygen atoms are disordered over two positions around the threefold axis of the tetrahedron. The site occupancies for the disordered atoms were refined and they are 0.56(1) and 0.44(1). A tert-butyl moiety was also found to be disordered, where the terminal carbon atoms occupy two alternative positions with refined occupation factors of $0.52(2)$ and $0.48(2)$.

Complex 2. The crystals of this complex are sensitive to solvent lost, so these crystals were handled in protective oil. A colorless irregular block was selected for X-ray analysis and isolated in a glass capillary. Non-H atoms were refined with anisotropic displacement parameters, except for the solvent of crystallization and the oxygen 
atoms of the perchlorate counterion, which are disordered over two alternative positions with occupancy factors of 0.63(1) and 0.37(1). Hydrogen atoms of the alcohol group (methanol) and the water molecules were not found on the Fourier map. $\mathrm{H}$ atoms bonded to carbon atoms were included in the refinement list using the same method as in complex 1. Further relevant crystallographic data for complexes $\mathbf{1}$ and $\mathbf{2}$ are summarized in Table 1.

\section{Results and Discussion}

\section{Synthesis and physical characterization}

The hexadentate $\mathrm{H}_{2} \mathrm{~L}$ pro-ligand is derived from alkyldiamines containing phenolate-type and $\alpha$-pyridyl pendant arms. The characterization of $\mathrm{H}_{2} \mathrm{~L}$ was unambiguously established by ${ }^{1} \mathrm{H}$ NMR spectroscopy and melting point techniques as reported in the literature. ${ }^{19}$

The $\mathrm{H}_{2} \mathrm{~L}$ pro-ligand reacts in methanol with trivalent metals to form the stable cationic $\left[\mathrm{M}^{\mathrm{III}}(\mathrm{L})\right]^{+}$complexes. These were isolated in high yields as the perchlorate salts. The complexes are soluble in a variety of organic solvents
$\left(\mathrm{CH}_{2} \mathrm{Cl}_{2}, \mathrm{CH}_{3} \mathrm{CN}, \mathrm{CH}_{3} \mathrm{OH}, \mathrm{THF}\right)$ and are exceedingly stable in these solvents. However, the complexes are insoluble in water. Molar conductivity measurements in $\mathrm{CH}_{3} \mathrm{CN}$ for all complexes showed values in the range 110$125 \Omega^{-1} \mathrm{~cm}^{2} \mathrm{~mol}^{-1}\left(25^{\circ} \mathrm{C}\right)$, indicating their $1: 1$ electrolyte behavior. ${ }^{25}$ This is consistent with the stoichiometry determined from elemental analysis.

\section{Description of the crystal structures of complexes 1 and $\mathbf{2}$}

An ORTEP plot ${ }^{26}$ of complex $\mathbf{1}$ is shown in Figure 1 and selected bond lengths and angles are summarized in Table 2 . The compound crystallizes in the space group P $\overline{1}$ with two molecules of the $\left[\mathrm{Mn}^{\mathrm{III}}(\mathrm{L})\right]^{+}$cation, two perchlorate counterions and one water molecule in the asymmetric unit. Considering the reduced formula $[\mathrm{Mn}(\mathrm{L})]\left[\mathrm{ClO}_{4}\right] \cdot 0.5 \mathrm{H}_{2} \mathrm{O}$, the value of $\mathrm{Z}$ is 4 which is unusual for a triclinic crystal system.

In the structure of $\mathbf{1}$, the $\mathrm{Mn}^{3+}$ ion lies in a distorted octahedral geometry, in which the two halves of the symmetrical ligand $\mathrm{L}^{2-}$ are coordinated in a facial arrangement ( $\mathrm{acc}-\mathrm{N}_{2} \mathrm{O}$ set): two phenolate oxygen and two

Table 1. Crystal data and structure refinement for complexes $\mathbf{1}$ and $\mathbf{2}$

\begin{tabular}{|c|c|c|}
\hline Complex & 1 & 2 \\
\hline Empirical formula & $\mathrm{MnC}_{44} \mathrm{H}_{61} \mathrm{~N}_{4} \mathrm{O}_{6,5} \mathrm{Cl}$ & $\mathrm{GaC}_{45} \mathrm{H}_{68} \mathrm{~N}_{4} \mathrm{O}_{9} \mathrm{Cl}$ \\
\hline Formula weight & 840.36 & 914.20 \\
\hline Temperature/ (K) & 293(2) & 293(2) \\
\hline Crystal system & Triclinic & monoclinic \\
\hline Space group & $\mathrm{P} \overline{1}$ & $\mathrm{P} 2 / \mathrm{c}$ \\
\hline \multicolumn{3}{|l|}{ Unit cell dimensions } \\
\hline $\mathrm{a} /(\AA)$ & $13.402(1)$ & $20.843(4)$ \\
\hline $\mathrm{b} /(\AA)$ & $17.182(16)$ & $12.842(12)$ \\
\hline c/ $(\AA)$ & $20.044(2)$ & $19.637(4)$ \\
\hline$\alpha /\left(^{\circ}\right)$ & $88.782(9)$ & \\
\hline$\beta /\left(^{\circ}\right)$ & $85.814(8)$ & $112.89(3)$ \\
\hline$\gamma /\left(^{\circ}\right)$ & $83.346(7)$ & \\
\hline Volume/ $\left(\AA^{3}\right)$ & $4572.1(7)$ & $4842.2(16)$ \\
\hline $\mathrm{Z}$, calculated density/ $\left(\mathrm{g} \mathrm{cm}^{-3}\right)$ & $4 / 1.221$ & $4 / 1.254$ \\
\hline Absorption coefficient/ $\left(\mathrm{mm}^{-1}\right)$ & 0.396 & 0.678 \\
\hline $\mathrm{F}(000)$ & 1788 & 1944 \\
\hline Crystal size/ $\left(\mathrm{mm}^{3}\right)$ & $0.50 \times 0.46 \times 0.30$ & $0.50 \times 0.43 \times 0.3$ \\
\hline Theta range for data collection/ $\left({ }^{\circ}\right)$ & $1.02-24.97$ & $1.06-25.00$ \\
\hline \multirow[t]{3}{*}{ Index ranges } & $-15 \leq \mathrm{h} \leq 15$ & $-24 \leq \mathrm{h} \leq 0$ \\
\hline & $-20 \leq \mathrm{k} \leq 20$ & $0 \leq \mathrm{k} \leq 15$ \\
\hline & $-23 \leq 1 \leq 00$ & $-21 \leq 1 \leq 23$ \\
\hline Reflections collected / unique & $16560 / 16054\left(\mathrm{R}_{\mathrm{int}}=0.0370\right)$ & $8789 / 8537\left(\mathrm{R}_{\mathrm{int}}=0.0631\right)$ \\
\hline Absorption correction & $\Psi$-scan & $\Psi$-scan \\
\hline Maximum and minimum transmission & 0.8911 and 0.8113 & 0.821 and 0.731 \\
\hline Refinement method & Full-matrix least-squares on $\mathrm{F}^{2}$ & Full-matrix least-squares on $\mathrm{F}^{2}$ \\
\hline Data/ restraints / parameters & 16054 / 78 / 974 & 8537 / 64 / 519 \\
\hline Goodness-of-fit on $\mathrm{F}^{2}$ & 1.061 & 0.935 \\
\hline Final $R$ indices $[I>2 \sigma(I)]$ & $\begin{array}{l}\mathrm{R}_{1}=0.0843 \\
w \mathrm{R}_{2}=0.2424\end{array}$ & $\begin{array}{c}\mathrm{R}_{1}=0.0739 \\
w \mathrm{R}_{2}=0.1883\end{array}$ \\
\hline $\mathrm{R}$ indices (all data) & $\begin{array}{l}\mathrm{R}_{1}^{2}=0.1983 \\
w \mathrm{R}_{2}=0.2934\end{array}$ & $\begin{array}{l}\mathrm{R}_{1}=0.2145 \\
w \mathrm{R}_{2}=0.2131\end{array}$ \\
\hline Largest differential peak and hole/ (e $\AA^{3}$ ) & $0.902 \mathrm{e}-0.685$ & 0.724 e -0.564 \\
\hline
\end{tabular}




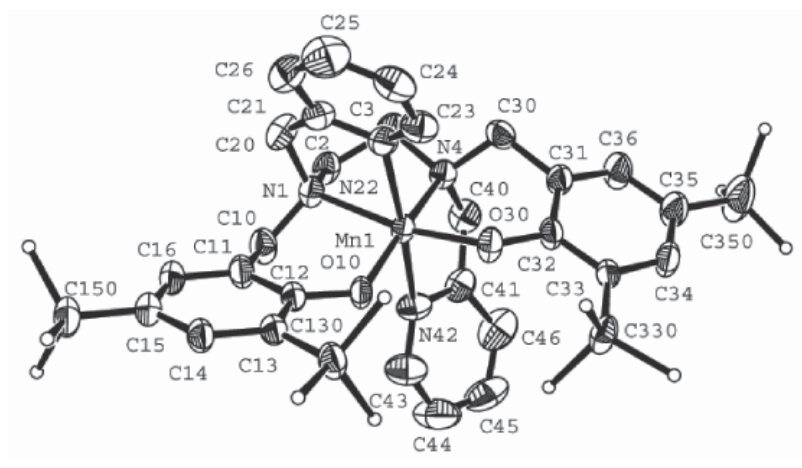

Figure 1. Ortep ${ }^{26}$ view of the $\left[\mathrm{Mn}^{\mathrm{II}}(\mathrm{L})\right]^{+}$cation in 1, showing the atom labeling scheme. Displacement ellipsoids are shown at the 50\% probability level.

Table 2. Selected bond lengths $(\AA)$ and angles $\left(^{\circ}\right)$ for complex 1

\begin{tabular}{llll}
\hline Mn1-O10 & $1.856(4)$ & Mn1-N1 & $2.099(5)$ \\
Mn1-O30 & $1.866(4)$ & Mn1-N22 & $2.248(6)$ \\
Mn1-N4 & $2.088(5)$ & Mn1-N42 & $2.282(6)$ \\
& & & \\
O10-Mn1-O30 & $92.72(18)$ & N1-Mn1-N22 & $78.5(2)$ \\
O10-Mn1-N4 & $168.7(2)$ & O10-Mn1-N42 & $90.8(2)$ \\
O30-Mn1-N4 & $91.6(2)$ & O30-Mn1-N42 & $93.9(2)$ \\
O10-Mn1-N1 & $93.3(2)$ & N4-Mn1-N42 & $78.5(2)$ \\
O30-Mn1-N1 & $168.7(2)$ & N1-Mn1-N42 & $95.6(2)$ \\
N4-Mn1-N1 & $84.3(2)$ & N22-Mn1-N42 & $173.7(2)$ \\
O10-Mn1-N22 & $91.7(2)$ & C12-O10-Mn1 & $129.8(4)$ \\
O30-Mn1-N22 & $91.8(2)$ & C32-O30-Mn1 & $129.8(4)$ \\
N4-Mn1-N22 & $98.6(2)$ & & \\
\hline
\end{tabular}

tertiary nitrogen atoms of ethylenediamine form the equatorial plane, with atoms of the same type in cis positions with respect to each other, while two pyridine groups that are mutually trans, complete the coordination sphere of the $\mathrm{Mn}^{\mathrm{III}}$ cation. As can be observed in Figure 1 the donor atoms N1, N22 and O10 occupy one face of the octahedron while N4, N42 and O30 occupy the other face. The axial Mn- $\mathrm{N}_{\text {pyridine }}$ bond distances of 2.248(6) and 2.282(6) $\AA$ in complex $\mathbf{1}$ are the longest of the coordination sphere and this is consistent with a Jahn-Teller distortion of this highspin $\mathrm{Mn}(\mathrm{III})\left(\mathrm{d}^{4}\right)$ ion. On the other hand, these bond distances are somewhat longer than the corresponding Mn$\mathrm{N}_{\text {pyridine }}$ bond distances observed in the reported $\left[\mathrm{Mn}^{\mathrm{III}} \text { (bbpen) }\right]^{+}$complex $(2.237(5) \text { and } 2.252(5) \AA)^{11}$ despite the fact that the equatorial $\mathrm{Mn}-\mathrm{N}_{\text {amine }}$ bonds (av. 2.094(5) $\AA$ in 1 and 2.101(4) $\AA$ in $\left.\left[\mathrm{Mn}^{\mathrm{II}}(\text { bbpen })\right]^{+}\right)$and the equatorial $\mathrm{Mn}-\mathrm{O}_{\text {phenolate }}$ bonds (av. 1.861(4) $\AA$ in $\mathbf{1}$ and 1.867(4) $\AA$ in $\left.\left[\mathrm{Mn}^{\mathrm{II}}(\text { bbpen })\right]^{+}\right)$are very similar. Furthermore, as described for $\left[\mathrm{Mn}^{\mathrm{III}}(\text { bbpen })\right]^{+}$, the $\mathrm{Mn}^{\mathrm{III}}-\mathrm{N}_{\text {pyridine }}$ bond distances in $\mathbf{1}$ are significantly shorter $(\approx 0.2 \AA)$ than those found in other $\mathrm{Mn}^{\mathrm{III}}-\mathrm{N}_{\text {pyridine }}$ complexes with Jahn-Teller distortion ${ }^{27-30}$ and this structural feature can be explained in terms of the ring strain caused by the rigidity of the five-membered rings formed with the pyridyl arms in the $\left[\mathrm{Mn}^{\mathrm{III}}(\text { bbpen })\right]^{+11}$ and the $\left[\mathrm{Mn}^{\mathrm{III}}(\mathrm{L})\right]^{+}$complexes.

The Mn- $\mathrm{N}_{\text {amine }}$ bonds are also somewhat longer than those for other known $\mathrm{Mn}$ (III) complexes ${ }^{31}$ containing only $\mathrm{Mn}^{\mathrm{III}}-\mathrm{N}_{\text {amine }}$ bonds in the equatorial plane, and this is a consequence of the weak trans effect of the shorter $\mathrm{Mn}^{\mathrm{II}}$ $\mathrm{O}_{\text {phenolate }}$ bond distances. These bond distances are shorter than $\mathrm{Mn}-\mathrm{O}_{\text {phenolate }}$ bond distances observed for structurally characterized manganese $\mathrm{e}^{\mathrm{III}}$ compounds..$^{28-30,32-34}$ The trans angles at the $\mathrm{Mn}^{\mathrm{III}}$ center in $\mathbf{1}$ are in the range of 168.7(2)$173.7(2)^{\circ}$ with the greatest distortion from linearity occurring at the O10-Mn-O4 and O30-Mn-N1 angles.

A perspective view of complex $\mathbf{2}$ is shown in Figure 2 and selected bond lengths and angles are summarized in Table 3. The gallium complex crystallizes in the monoclinic system, space group $P 2_{1} / c$. The asymmetric unit consists of a mononuclear $\left[\mathrm{Ga}^{\mathrm{III}}(\mathrm{L})\right]^{+}$cation, one methanol molecule and two water molecules as the crystallization solvent, and one uncoordinated perchlorate anion. As expected, the distorted octahedral geometry is very similar to the coordination geometry in complex $\mathbf{1}$ and also similar to that previously reported for the $\left[\mathrm{Ga}^{\mathrm{III}}(\text { Clbbpen })\right]^{+}$complex. ${ }^{16}$ In complex 2 , the face of the octahedron is again occupied by N1, N22 and O10 while the other face is occupied by $\mathrm{N} 4, \mathrm{~N} 42$ and $\mathrm{O} 30$.

Table 3. Selected bond lengths $(\AA)$ and angles $\left({ }^{\circ}\right)$ for complex 2

\begin{tabular}{llll}
\hline Ga1-O10 & $1.854(4)$ & Ga1-N42 & $2.105(5)$ \\
Ga1-O30 & $1.859(4)$ & Ga1-N4 & $2.155(5)$ \\
Ga1-N22 & $2.105(5)$ & Ga1-N1 & $2.160(5)$ \\
& & & \\
O10-Ga1-O30 & $95.31(17)$ & N42-Ga1-N4 & $78.68(19)$ \\
O10-Ga1-N22 & $95.95(18)$ & O10-Ga1-N1 & $91.71(17)$ \\
O30-Ga1-N22 & $89.22(18)$ & O30-Ga1-N1 & $166.64(18)$ \\
O10-Ga1-N42 & $91.26(19)$ & N22-Ga1-N1 & $78.75(19)$ \\
O30-Ga1-N42 & $97.34(19)$ & N42-Ga1-N1 & $93.84(19)$ \\
N22-Ga1-N42 & $169.8(2)$ & N4-Ga1-N1 & $82.93(17)$ \\
O10-Ga1-N4 & $168.20(18)$ & C12-O10-Ga1 & $130.8(4)$ \\
O30-Ga1-N4 & $92.11(18)$ & C32-O30-Ga1 & $129.0(4)$ \\
N22-Ga1-N4 & $93.31(18)$ & & \\
\hline
\end{tabular}

The identical Ga- $\mathrm{N}_{\text {pyridine }}$ bond distances (2.105(5) $\AA$ ) in complex $\mathbf{2}$ are similar to those found in the [Ga $\left.{ }^{\mathrm{III}}(\mathrm{Clbbpen})\right]^{+}$ complex (2.121(2) and 2.107(2) ̊̊), while the Ga- $\mathrm{O}_{\text {phenolate }}$ bond distances in complex 2 (1.854(4) and 1.859(4) A) are slightly shorter than those observed in $\left[\mathrm{Ga}^{\mathrm{III}}(\mathrm{Clbbpen})\right]^{+}$ (1.860(2) and 1.871(2) $\AA) .{ }^{16}$ Unlike the findings for complex 2 , the $\left[\mathrm{Ga}^{\mathrm{III}}(\mathrm{Clbbpen})\right]^{+}$complex shows a chloride atom in the para- position relative to each of the phenol groups. A significant difference is observed on comparing the Ga$\mathrm{N}_{\text {amine }}$ bond distances for the two the complexes: 2.155(5) / 2.160(5) $\AA$ in complex 2 and 2.158(2) / 2.180(2) $\AA$ in $\left[\mathrm{Ga}^{\mathrm{III}}(\mathrm{Clbbpen})\right]^{+}$. 


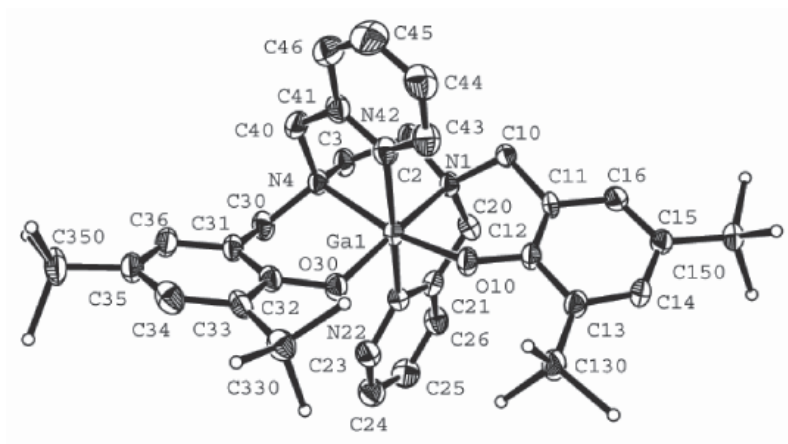

Figure 2. A perspective view ${ }^{26}$ of the $\left[\mathrm{Ga}^{\mathrm{III}}(\mathrm{L})\right]^{+}$cation in $\mathbf{2}$, showing the atom labeling scheme. Displacement ellipsoids are shown at the 50\% probability level.

In complex 2 the trans angles involving N42-Ga-N22, O30-Ga-N1 and O10-Ga-N4 averaged 168.2(18) ${ }^{\circ}$, whereas the cis angles involving $\mathrm{N}_{\text {pyridine }}-\mathrm{Ga}_{\mathrm{N}} \mathrm{N}_{\text {amine }}$ and $\mathrm{N}_{\text {pyridine }}$-Ga$\mathrm{O}_{\text {phenolate }}$ averaged $85.48(18)^{\circ}$, providing a minimally distorted octahedral geometry around the central metallic core. Angles and distances for the atoms are relatively similar to those reported for the gallium ${ }^{\mathrm{III}}$ complexes. $^{35-42}$

\section{${ }^{1}$ H NMR spectra of complexes 2 and 3}

${ }^{1} \mathrm{H}$ NMR spectra for complexes $\mathbf{2}$ and $\mathbf{3}$ are shown in Figure S1 (see Supplementary Information). The attribution of the signals was carried out with the help of tabulated data reported in the literature..$^{43}$ The bidimensional COSY technique was used to verify the couplings between protons. ${ }^{1} \mathrm{H}$ chemical shifts, assignments and multiplicity for complexes $\mathbf{2}$ and $\mathbf{3}$ can be seen in Table $\mathrm{S} 1$ in the supplementary information.

The ${ }^{1} \mathrm{H}$ and ${ }^{13} \mathrm{C}$ NMR spectra of the $\mathrm{H}_{2} \mathrm{~L}$ pro-ligand have been reported in the literature ${ }^{19}$. The NMR spectra of the metal complexes $\mathbf{2}$ and $\mathbf{3}$ showed a differentiation of almost all the hydrogen atoms because they are in different chemical environments due to the rigid structure in which the ligand lies when it is coordinated to the metal center.

The ${ }^{1} \mathrm{H}$ NMR spectra of the metal complexes $\mathbf{2}$ and $\mathbf{3}$ (Figure $\mathrm{S} 1$ ) were recorded in $\mathrm{CD}_{3} \mathrm{CN}$ and were very similar to each other with the exception of the region corresponding to the methylene hydrogen atoms $\left(\mathrm{H}_{2}, \mathrm{H}_{2}\right.$,). In these spectra, two sets of resonance signals were observed; one for the pyridyl groups $(\delta 8.95-7.22)$ and the other for the hydroxybenzyl groups $(\delta$ 7.16-6.97).

The singlet at $\delta 3.76$ in the spectrum of the $\mathrm{H}_{2} \mathrm{~L}$ proligand is split into four doublets in the spectra of both complexes, attributed to the eight non equivalent methylene hydrogen atoms $\left(\mathrm{H}_{2}, \mathrm{H}_{2}\right)$. In complex 2 these signals appeared at $\delta 4.57$ and $\delta 4.27\left(2 \mathrm{H}_{2 \mathrm{py}}, \mathrm{H}_{2}{ }^{\prime} \mathrm{py}\right)$ and at $\delta 4.02$ and $\delta 3.85\left(2 \mathrm{H}_{2 \mathrm{ph}}, \mathrm{H}_{2^{\prime} \mathrm{ph}}\right)$, whereas in complex 3 they appeared at $\delta 4.47$ and $\delta 4.20\left(2 \mathrm{H}_{2 \mathrm{py}}, \mathrm{H}_{2}{ }^{\prime p y}\right)$ and at $\delta 4.31$ and $\delta 3.85\left(2 \mathrm{H}_{2 \mathrm{ph}}, \mathrm{H}_{2}{ }^{\prime} \mathrm{ph}\right)$.

The two doublets at $\delta 3.27$ and $\delta 2.96$ correspond to the methylene hydrogen atoms of the ethylenediamine backbone $\left(\mathrm{H}_{1}, \mathrm{H}_{1}\right)$, which also became nonequivalent upon complexation in complex $\mathbf{2}$. In complex $\mathbf{3}$ these signals appeared at $\delta 3.35$ and $\delta 3.15$. The four tert-butyl groups appeared as a single signal at $\delta 1.24$ in complex 2 and as two signals in complex $\mathbf{3}(\delta 1.36$ and $\delta 1.29)$.

In the ${ }^{1} \mathrm{H}$ NMR spectrum of complex 2 the chemical shifts of the solvent residual peak $\left(\mathrm{CD}_{3} \mathrm{CN}\right)$ and the water peak were determined at $\delta 1.99$ and $\delta 2.22$, respectively. ${ }^{44}$ In the spectrum of complex 3 these signals appeared at $\delta 2.00$ and $\delta 2.19$, respectively.

\section{Electrochemistry}

The electrochemical data are summarized in Table 4. The square wave voltammogram of complex 1 in $\mathrm{CH}_{2} \mathrm{Cl}_{2}$ at $298 \mathrm{~K}$ (Figure 3) displays three reversible oxidation processes at $1.15,0.36$ and $-0.65 \mathrm{~V} v s$. $\mathrm{Fc}^{+} / \mathrm{Fc}$. The cathodic process corresponds to the $\mathrm{Mn}^{\mathrm{II}} / \mathrm{Mn}^{\mathrm{III}}$ couple, and the anodic process at $1.15 \mathrm{~V}$ can be attributed to the reversible formation of two-coordinated phenoxyl radicals. Interestingly, the redox potential at $0.36 \mathrm{~V}$ can be attributed either to the $\mathrm{Mn}^{\mathrm{III}} / \mathrm{Mn}^{\mathrm{IV}}$ or phenolate/phenoxyl couples. Spectroelectrochemical and coulometric studies (videinfra), under the same experimental conditions as those employed in the square wave voltammetry, revealed that in fact the two processes occur simultaneously with the $\left[\mathrm{Mn}^{\mathrm{IV}}\left(\mathrm{L}^{\circ}\right)\right]^{3+}$ trication being generated in $\mathrm{CH}_{2} \mathrm{Cl}_{2}$ solution. The only similar species are those reported by Wieghardt and co-workers ${ }^{6-8}$ in which $\mathrm{Mn}^{\mathrm{IV}}$ complexes showed coordinated phenoxyl radicals. Recently, Chaudhuri and

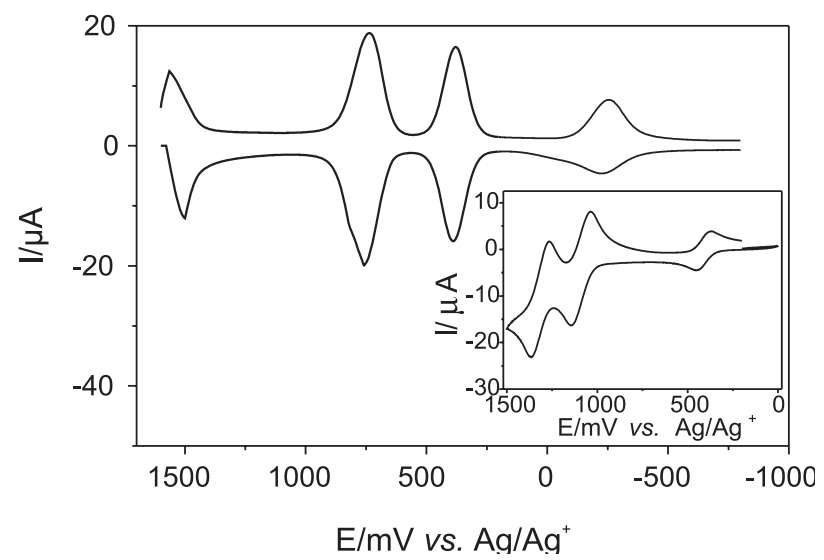

Figure 3. Square wave voltammogram of complex $\mathbf{1}$ in $\mathrm{CH}_{2} \mathrm{Cl}_{2}(0.1 \mathrm{~mol}$ $\left.\mathrm{dm}^{-3}\left[(\mathrm{TBA}) \mathrm{PF}_{6}\right]\right)$ : glass carbon working electrode. Conditions: see Table 4. Inset: cyclic voltammogram of complex 2. 
Table 4. Redox potentials ${ }^{\mathrm{a}}$ and electronic spectral data for the complexes

\begin{tabular}{lccccc}
\hline & $\mathrm{E}_{1 / 2}{ }^{1 / \mathrm{V} v s .} \mathrm{Fc} / \mathrm{Fc}$ & $\mathrm{E}_{1 / 2}{ }^{2} / \mathrm{V} v s . \mathrm{Fc}^{+} / \mathrm{Fc}$ & $\mathrm{E}_{1 / 2}{ }^{3} / \mathrm{V} v s . \mathrm{Fc}^{+} / \mathrm{Fc}$ & $\begin{array}{c}\lambda 1 / \mathrm{nm} \\
\left(\varepsilon / \mathrm{dm}^{3} \mathrm{~mol}^{-1} \mathrm{~cm}^{-1}\right)\end{array}$ & $\begin{array}{c}\lambda^{2} / \mathrm{nm}^{2} \\
\left(\varepsilon / \mathrm{dm}^{3} \mathrm{~mol}^{-1} \mathrm{~cm}^{-1}\right)\end{array}$ \\
\hline $\mathbf{1}^{\mathrm{b}}$ & 1.15 & 0.36 & -0.65 & $558(2978)$ & $394(5465)$ \\
$\mathbf{2}^{\mathbf{c}}$ & 0.90 & 0.68 & - & - & - \\
$\mathbf{3}^{\mathrm{b}}$ & 0.87 & 0.69 & - & - & - \\
$\mathbf{4}^{\mathrm{b}}$ & 1.07 & 0.73 & -1.2 & $654(6854)$ & $336\left(\mathrm{e}>10^{4}\right)$ \\
\hline
\end{tabular}

${ }^{\mathrm{a}}$ Conditions: $\left[\right.$ complex] $=10^{-3}-10^{-4} \mathrm{~mol} \mathrm{dm}^{-3}$ in $\mathrm{CH}_{2} \mathrm{Cl}_{2}\left(0.1 \mathrm{~mol} \mathrm{dm}^{-3}\right.$ [(TBA)PF ]; glassy carbon working electrode; platinum wire counter electrode; $\mathrm{Ag} / \mathrm{Ag}^{+}$reference electrode; $\mathrm{T}=298 \mathrm{~K}$. The $\mathrm{Fc}^{+} / \mathrm{Fc}$ couple $\left(E^{\circ}=400 \mathrm{mV} v s . \mathrm{NHE}\right)^{18}$ was used as an internal standard $\left(\mathrm{E}_{1 / 2}=385 \mathrm{mV} v \mathrm{~s} . \mathrm{Ag} / \mathrm{Ag}^{+}\right) ;{ }^{\mathrm{b}} \mathrm{SWV} ;{ }^{\mathrm{c}} \mathrm{CV}$.

co-workers ${ }^{7}$ reported $\mathrm{Mn}^{\mathrm{IV}}$-radical complexes which are able to catalyze the oxidation of 3,5-di-tert-butylcatechol in the presence of molecular oxygen as the sole oxidant to afford 3,5-di-tert-butylquinone, quantitatively.

In complex 1 , the redox couple $\mathrm{Mn}^{\mathrm{II}} / \mathrm{Mn}^{\mathrm{II}}$ is shifted by $300 \mathrm{mV}$ to more negative potentials in relation to the $\left[\mathrm{Mn}^{\mathrm{III}} \text { (bbpen) }\right]^{+}$complex ${ }^{11}$ as a consequence of the electron donating effect of the tert-butyl groups in the $p$-position of the phenol in the ligand.

Complexes 2 and 3 contain redox-inactive $\mathrm{Ga}^{\mathrm{III}}$ and $\mathrm{In}^{\mathrm{III}}$ ions, respectively. Therefore, all redox activity observed must be ligand-centered. The two one-electron oxidations (Table 4) of $\mathbf{2}$ (see inset in Figure 3) and $\mathbf{3}$ (see inset in Figure S2, Supplementary Information) are assigned to the successive formation of one- and twocoordinated phenoxyl radicals, in good agreement with results reported in the literature. ${ }^{1,6,9}$ It is important to note that the anodic $E^{1 / 2}$ values for the $\mathrm{Ga}^{\mathrm{III}}$ and $\mathrm{In}^{\mathrm{III}}$ complexes are comparable to the redox potential observed for the generation of the trication $\left[\mathrm{Mn}^{\mathrm{IV}}\left(\mathrm{L}^{\circ}\right)\right]^{3+}$ and are thus in full agreement with this assignment. On the other hand, on the timescale of a coulometric experiment at ambient temperature only the dication $\left[\mathrm{Ga}\left(\mathrm{L}^{\circ}\right)\right]^{2+}$ is stable. Thus, oxidation of complex 2 by one electron equivalent at a constant potential of $0.75 \mathrm{~V} v s$. $\mathrm{Fc}^{+} / \mathrm{Fc}$ produces a yellowgreen solution of the respective dication. The trication $\left[\mathrm{M}\left(\mathrm{L}^{*}\right)\right]^{3+}$ is unstable under these conditions.

In the potential range +1.8 to $-1.0 \mathrm{~V} v s$. $\mathrm{Fc}^{+} / \mathrm{Fc}$, the $\mathrm{CVs}$ and square-wave voltammogram of complex 4 (Figure S2) reveal three reversible one-electron transfer processes. The cathodic process at $-1.2 \mathrm{~V} \mathrm{vs.} \mathrm{Fc}^{+} / \mathrm{Fc}$ is assigned to a metal-centered reduction of $\mathrm{Fe}^{\mathrm{III}}$ to $\mathrm{Fe}^{\mathrm{II}}$, whereas the two oxidation waves $(0.73$ and $1.07 \mathrm{~V} v s$. $\mathrm{Fc}^{+} / \mathrm{Fc}$ ) are ligand-centered successive phenoxyl radical formation processes. These results suggest that no formation of $\mathrm{Fe}^{\mathrm{IV}}$ species occurs. The reduction potential in complex 4 is $0.4 \mathrm{~V}$ cathodic shifted when compared to that reported for the $\left[\mathrm{Fe}^{\mathrm{III}}(\text { bbpen })\right]^{+}$complex $(-0.82 \mathrm{~V} v s$. $\mathrm{Fc}^{+} / \mathrm{Fc}$ ) which is also derived from the ethylenediamine backbone containing phenol and pyridyl pendant arms. ${ }^{45}$ However, in this complex no substituents are found in the ortho- and para-positions of the phenol groups. Moreover, from an overall view of these results one can conclude that the electron-donor tert-butyl substituents in the orthoand para-positions of the phenol groups significantly enhance the basicity of the oxygen atoms in $\mathrm{H}_{2} \mathrm{~L}$.

Since the redox potentials $\mathrm{E}_{1 / 2}$ for complexes 2-4 are very similar, we conclude that the redox chemistry is ligand-based. Thus, the scheme shown below summarizes the phenoxyl radical species generated from the complexes via one-electron oxidation reactions.

$$
[M(L)]^{+} \frac{-e^{-}}{+e^{-}}\left[M\left(L^{\bullet}\right)\right]^{2+} \frac{-e^{-}}{+e^{-}}\left[M\left(L^{\bullet \bullet}\right)\right]^{3+}
$$

where: $\mathrm{M}=\mathrm{Ga}^{\mathrm{III}}$, In ${ }^{\mathrm{III}}$ or $\mathrm{Fe}^{\mathrm{III}}$; one $(\bullet)$ or two $(\bullet \bullet)$ dots indicate the presence of one or two phenoxyl radicals.

In previous studies on tris(phenolate)-metal complexes $(\mathrm{M}=\mathrm{Ga}, \mathrm{Co}, \mathrm{Fe})$, Wieghardt and co-workers ${ }^{6,10}$ established that the redox potentials for the $\left[\mathrm{ML}^{\mathrm{c}}\right]^{+} /\left[\mathrm{ML}^{\mathrm{c}}\right]$ couples vary from $0.35 \mathrm{~V}$ vs. $\mathrm{Fc}^{+} / \mathrm{Fc}$ for the gallium complex to $0.38 \mathrm{~V} v s . \mathrm{Fc}^{+} / \mathrm{Fc}$ for the iron complex. It has been shown that these values correlate with the $\pi$-donor bond strength of the $\mathrm{M}-\mathrm{O}_{\text {phenolate }}$ bond which is relatively strong in $\mathrm{Ga}^{\mathrm{III}}$ $\left(\mathrm{d}^{0}\right)$, and even stronger in high-spin $\mathrm{Fe}^{\mathrm{III}}\left(\mathrm{d}^{5}\right)$ complexes. The same trend for the redox potentials was found in the study reported here, i.e., $\mathrm{E}_{1 / 2}$ is lower for complexes $\mathbf{2}$ and $\mathbf{3}$ than for complexes $\mathbf{1}$ and $\mathbf{4}$.

\section{Electronic spectra and spectroelectrochemistry}

The electronic spectra of complexes $\mathbf{1}$ and $\mathbf{4}$ measured in $\mathrm{CH}_{2} \mathrm{Cl}_{2}$ are shown in Figure 4 and the data are summarized in Table 4.

Complex 1 (Figure 4) shows a large band at $\lambda_{\text {max }} 558$ $\mathrm{nm}\left(\varepsilon 2978 \mathrm{dm}^{3} \mathrm{~mol}^{-1} \mathrm{~cm}^{-1}\right)$, attributed to the phenolate-to$\mathrm{Mn}^{\mathrm{III}}$ charge transfer transition (LMCT) from the $\pi_{\mathrm{p}}$ orbital on the phenolate oxygen to the half-filled $\mathrm{Mn}^{\mathrm{III}} \mathrm{d}_{\pi^{*}}{ }^{\mathrm{p}}$ orbital. The electronic spectrum displays an additional band at $\lambda_{\text {max }}$ $394 \mathrm{~nm}\left(\varepsilon 5465 \mathrm{dm}^{3} \mathrm{~mol}^{-1} \mathrm{~cm}^{-1}\right)$, which is also assigned to a LMCT process, but originated from the $\mathrm{p}_{\pi}$ orbital to the $\mathrm{d}_{\mathrm{\sigma}^{*}}$ orbital transition. The stronger interaction in $\mathbf{1}$ (due to 


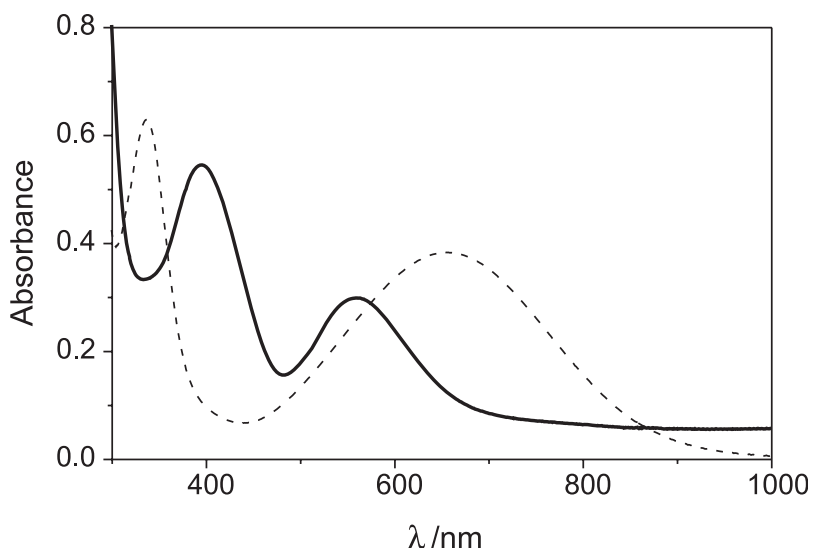

Figure 4. Electronic spectra in $\mathrm{CH}_{2} \mathrm{Cl}_{2}$ of complexes: 1 (solid line, $1.0 \mathrm{x}$ $10^{-4} \mathrm{~mol} \mathrm{dm}^{-3}$ ) and 4 (dashed line, $5.0 \times 10^{-5} \mathrm{~mol} \mathrm{dm}^{-3}$ ).

the shorter $\mathrm{Mn}^{\mathrm{III}}-\mathrm{O}_{\text {phenolate }}$ bond distance) is consistent with its lower energy phenolate-to-Mn(III) LMCT band at $\lambda_{\max }$ $558 \mathrm{~nm}$ compared with other $\mathrm{Mn}(\mathrm{III})$ complexes described in the literature for which this lower energy band lies in the $350-480 \mathrm{~nm}$ range. ${ }^{28-30} \mathrm{~A}$ similar result was found for the $\left[\mathrm{Mn}^{\mathrm{III}}(\text { bbpen })\right]^{+}$complex $\left(\lambda_{\max } 506 \mathrm{~nm}\right) .{ }^{11}$ However, the presence of electron-donating groups (tert-butyl) contributes to a greater bathochromic shift in the band of complex $\mathbf{1}$. The $\mathrm{p}_{\pi} \mathrm{d}_{\sigma^{*}}$ charge-transfer band is also shifted to lower energy in $\mathbf{1}$.

Figure 5 shows the spectral change in the $350-850 \mathrm{~nm}$ range during the oxidation of $\left[\mathrm{Mn}^{\mathrm{III}}(\mathrm{L})\right]^{+}$to the $\left[\mathrm{Mn}^{\mathrm{IV}}\left(\mathrm{L}^{\cdot}\right)\right]^{3+}$ species in a spectroelectrochemical experiment. The electronic spectrum of the electrochemically generated radical-manganese(IV) species shows two intense bands $\left(\varepsilon>10^{3} \mathrm{dm}^{3} \mathrm{~mol}^{-1} \mathrm{~cm}^{-1}\right)$ at $\lambda_{\text {max }} 538 \mathrm{~nm}$ and $\lambda_{\text {max }} 970 \mathrm{~nm}$. These values are significantly higher when compared to those observed for the $\left[\mathrm{Mn}^{\mathrm{IV}} \text { (bbpen) }\right]^{+}$complex $\left(\lambda_{\text {max }} 506\right.$ and $790 \mathrm{~nm}) .{ }^{11}$ Data for the Nernst plot shown in the inset of Figure 5 were obtained by recording the absorbance of the $538 \mathrm{~nm}$ band after equilibrium was established following selected potential steps. The $E^{0^{\prime}}=0.37 \mathrm{~V} v s$. $\mathrm{Fc}^{+} / \mathrm{Fc}$ and $n=2.23$ electron values obtained from this plot are in good agreement with the square wave and coulometric results. From these results we propose that both, the $\mathrm{Mn}^{\mathrm{III}}$ to $\mathrm{Mn}^{\mathrm{IV}}$ and the ligand-centered oxidation (phenolate to phenoxyl) processes occur simultaneously with similar redox potentials and formation of a $\mathrm{Mn}^{\mathrm{IV}}$ phenoxyl radical species in $\mathrm{CH}_{2} \mathrm{Cl}_{2}$.

Coulometry and spectroelectrochemical measurements for the reduction of complex $\mathbf{1}$ confirm the results obtained from the square wave voltammetric studies, indicating that this is also a one-electron transfer process $(n=0.90 \pm 0.1$ electron), possibly involving the $\mathrm{Mn}^{\mathrm{II}}$ complex $\left(E^{\circ}=\right.$ $\left.-0.64 \pm 0.05 \mathrm{~V} v s . \mathrm{Fc}^{+} / \mathrm{Fc}\right)$. However, the reduced pale red solution undergoes decomposition in a few minutes.

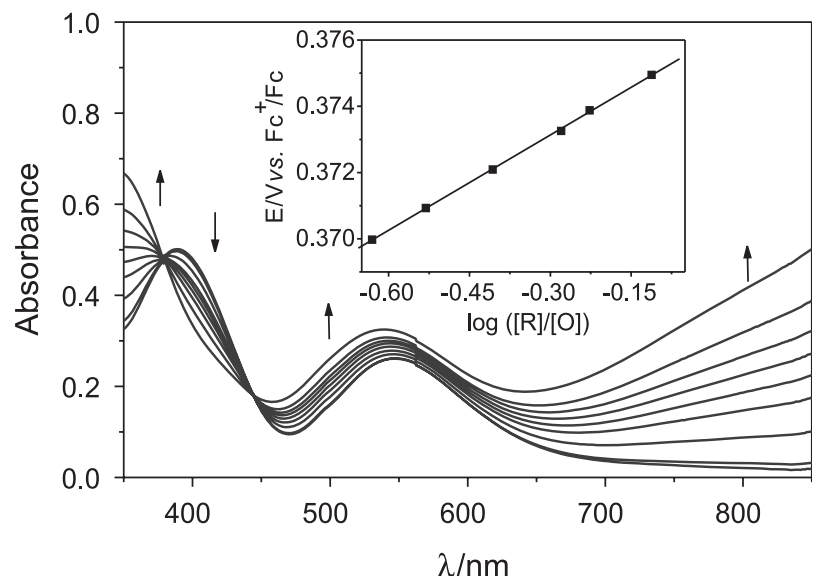

Figure 5. Spectral changes during spectropotentiostatic experiments with complex 1 in $\mathrm{CH}_{2} \mathrm{Cl}_{2}\left(0.1 \mathrm{~mol} \mathrm{dm}^{-3}\left[(\mathrm{TBA}) \mathrm{PF}_{6}\right]\right)$ at $298 \mathrm{~K}$. The inset shows the Nernst plot $\left(\mathrm{E}^{\circ}=0.37 \mathrm{~V} v s\right.$. $\left.\mathrm{Fc}^{+} / \mathrm{Fc}\right)$.

The UV-Vis spectrum of complex 4 (Figure 4) is dominated by intense absorption bands at $654 \mathrm{~nm}\left(\varepsilon>5864 \mathrm{dm}^{3} \mathrm{~mol}^{-1}\right.$ $\left.\mathrm{cm}^{-1}\right)$ and $336 \mathrm{~nm}\left(\varepsilon>10^{4} \mathrm{dm}^{3} \mathrm{~mol}^{-1} \mathrm{~cm}^{-1}\right)$ which may be assigned to phenolate- $\mathrm{Fe}^{\mathrm{III}}$ charge transfer transitions from $\mathrm{p}_{\mathrm{p}}$ orbitals to $\mathrm{d}_{\pi^{*}}$ and $\mathrm{d}_{\sigma^{*}}$ orbitals, respectively. These low energy transitions when compared with the $\left[\mathrm{Fe}^{\mathrm{III}}(\text { bbpen })\right]^{+}$complex ${ }^{45}$ confirm the significant effect of the electron-donor tert-butyl substituents. The monooxidized radical displays the typical intense phenoxyl radical bands at 390, 410 and $680 \mathrm{~nm}$, in good agreement with results reported in the literature. ${ }^{1,6}$ In the spectroelectrochemical study (reduction process), the application of potential near the $\mathrm{E}_{1 / 2}$ value $\left(-1.2 \mathrm{~V} v \mathrm{~s}\right.$. $\left.\mathrm{Fc}^{+} / \mathrm{Fc}\right)$ is followed by the disappearance of the phenolate- $\mathrm{Fe}^{\mathrm{III}}$ charge transfer transitions and the appearance of a new band around $530 \mathrm{~nm}\left(E^{\circ}=-1.09 \pm 0.06 \mathrm{~V} v s . \mathrm{Fc}^{+} / \mathrm{Fc}\right.$ and $n=0.85 \pm 0.1$ electron from the Nernst plot). The latter may be assigned to a $\mathrm{Fe}^{\mathrm{II}}$-pyridine charge transfer transition.

Complexes $\mathbf{2}$ and $\mathbf{3}$ are colorless in $\mathrm{CH}_{2} \mathrm{Cl}_{2}$, however, monooxidized forms of these complexes are yellow. The spectrum for the $\left[\mathrm{Ga}\left(\mathrm{L}^{\circ}\right)\right]^{2+}$ complex (Figure 6), generated electrochemically at controlled potentials, displays three bands in the UV-Vis region: 390 and $408 \mathrm{~nm}\left(\varepsilon>10^{3} \mathrm{dm}^{3}\right.$ $\mathrm{mol}^{-1} \mathrm{~cm}^{-1}$ ) and a transition at 600-900 nm of much lower intensity $\left(\varepsilon<10^{3} \mathrm{dm}^{3} \mathrm{~mol}^{-1} \mathrm{~cm}^{-1}\right)$. Similar spectra for many other phenoxyl radicals have been reported., ${ }^{1,6,9}$

\section{EPR spectroscopy}

The EPR spectra of complexes 1, 2 and $\mathbf{3}$ show no signal, since manganese ${ }^{\mathrm{III}}$, gallium ${ }^{\mathrm{III}}$ and indium ${ }^{\mathrm{III}}$ ions are EPR silent.

The X-band EPR spectrum (Figure 7a) of the electrochemically generated $\left[\mathrm{Mn}^{\mathrm{IV}}\left(\mathrm{L}^{*}\right)\right]^{3+}$ species $(1$ minute of electrolysis process) exhibits a signal at $g \approx 2.0$ (six lines 


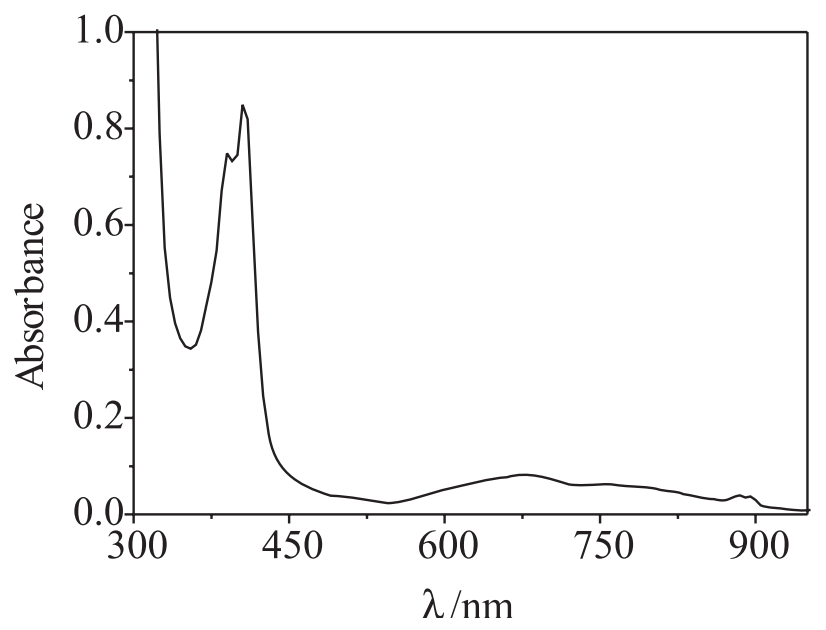

Figure 6. Electronic spectrum of the electrochemically generated phenoxyl radical complex [2 $]^{2+}$ in $\mathrm{CH}_{2} \mathrm{Cl}_{2}\left(0.1 \mathrm{~mol} \mathrm{dm}^{-3}\right.$ [(TBA)PF$\left.\left.{ }_{6}\right]\right)$ at $298 \mathrm{~K}$.

with $\Delta \mathrm{H} \approx 100 \mathrm{G})$ at $298 \mathrm{~K}$, typical of a $\mathrm{Mn}^{\mathrm{IV}}$ ion. Interestingly, in the same spectrum an isotropic signal at $g \approx$ $2.005(\Delta \mathrm{H} \approx 9.0 \mathrm{G})$ is clearly observed, which is typical of a phenoxyl radical. Thus, the EPR spectrum indicates the formation of an unusual $\mathrm{Mn}^{\mathrm{IV}}$-phenoxyl radical species in solution, in very good agreement with the electrochemical and spectroelectrochemical studies. In fact, observation of both of the individual processes (radical + $\mathrm{Mn}^{\mathrm{IV}}$ ) is possible at the beginning of the experiment indicating that the spins are most probably not coupled. However, after a short time ( one minute), these signals disappear and the formation of an isotropic signal centered at $g \approx 2.06$ (Figure 7b) becomes prominent. These results clearly indicate that the $\left[\mathrm{Mn}^{\mathrm{IV}}\left(\mathrm{L}^{\circ}\right)\right]^{3+}$ species is unstable under these experimental conditions and that a decomposition process, most probably with breaking of the $\mathrm{H}_{2} \mathrm{~L}$ pro-ligand, is taking place. Alternatively, it is reasonable to attribute the signal at $g=$ 2.005 to an uncoordinated phenoxyl radical since this EPR signal seems too narrow for a phenoxyl coordinated to a paramagnetic ion.

The X-band EPR spectra of $\left[\mathrm{Ga}\left(\mathrm{L}^{\circ}\right)\right]^{2+}$ (Figure 8) and $\left[\operatorname{In}\left(\mathrm{L}^{\circ}\right)\right]^{2+}$ (see inset in Figure 8) in $\mathrm{CH}_{2} \mathrm{Cl}_{2}$, generated electrochemically from complexes $\mathbf{2}$ and $\mathbf{3}$, respectively, were recorded at $298 \mathrm{~K}$. Both species exhibit typical S $=1 / 2$ signals ( $g=2.0049, \Delta \mathrm{H}=9.5$ Gauss) without hyperfine structure, which correspond to the phenoxyl radical..$^{1,6,9}$ The EPR spectrum simulated for $\left[\mathrm{Ga}\left(\mathrm{L}^{\circ}\right)\right]^{2+}{ }^{46}$ is also shown in Figure 8.

The X-band EPR spectrum of complex 4 (see Figure $\mathrm{S} 3$ at Suplementary Information) recorded in frozen $\mathrm{CH}_{2} \mathrm{Cl}_{2}$ solution displays a broad intense signal at $g \approx 4.3$. This well resolved signal is typical of rhombically distorted, highspin monomeric iron(III) complexes $(\mathrm{S}=5 / 2)$. In the coulometric experiment at room temperature, no apparent
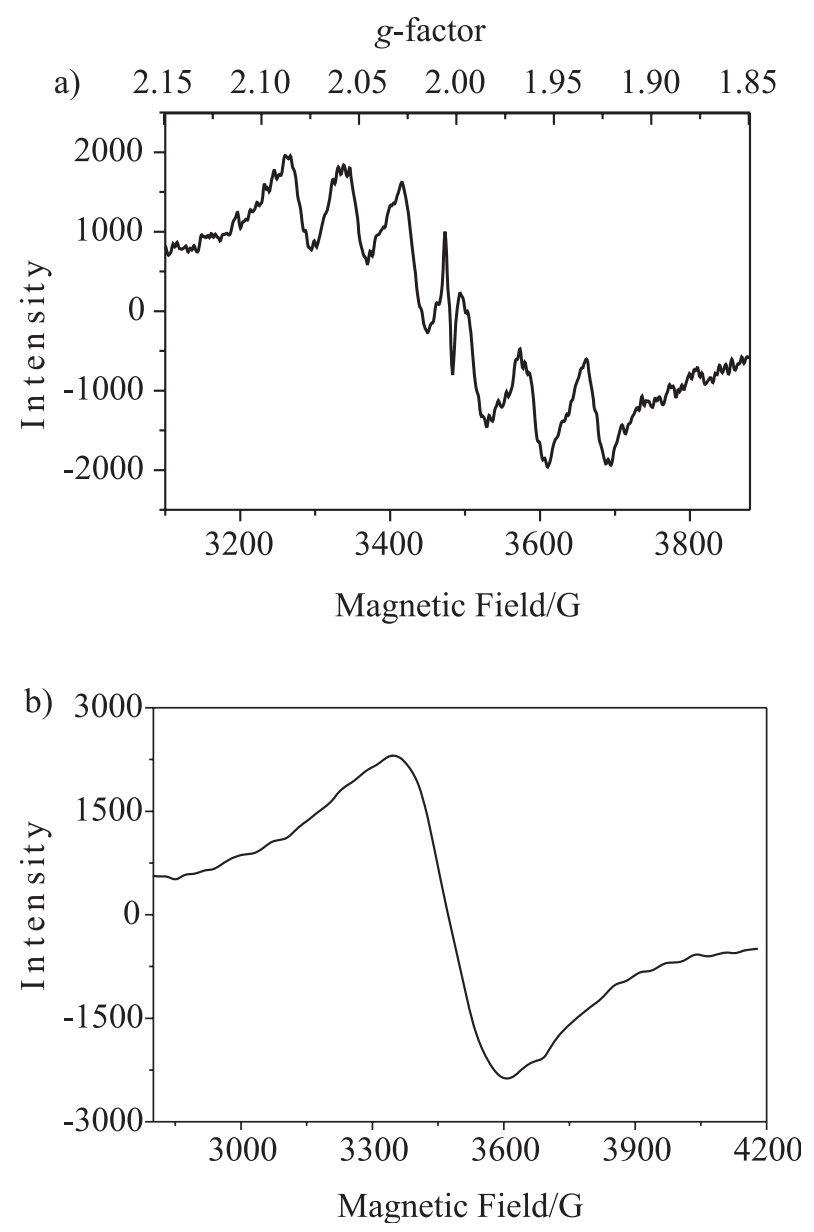

Figure 7. X-band EPR spectra of the electrochemically generated $\left[\mathrm{Mn}^{\mathrm{IV}}\left(\mathrm{L}^{-}\right)\right]^{3+}$ species in $\mathrm{CH}_{2} \mathrm{Cl}_{2}\left(0.1 \mathrm{~mol} \mathrm{dm}^{-3}\left[(\mathrm{TBA}) \mathrm{PF}_{6}\right]\right)$ at $298 \mathrm{~K}$ : (a) beginning of the electrolysis process ( 1 minute), (b) after 2 minutes of electrolysis.

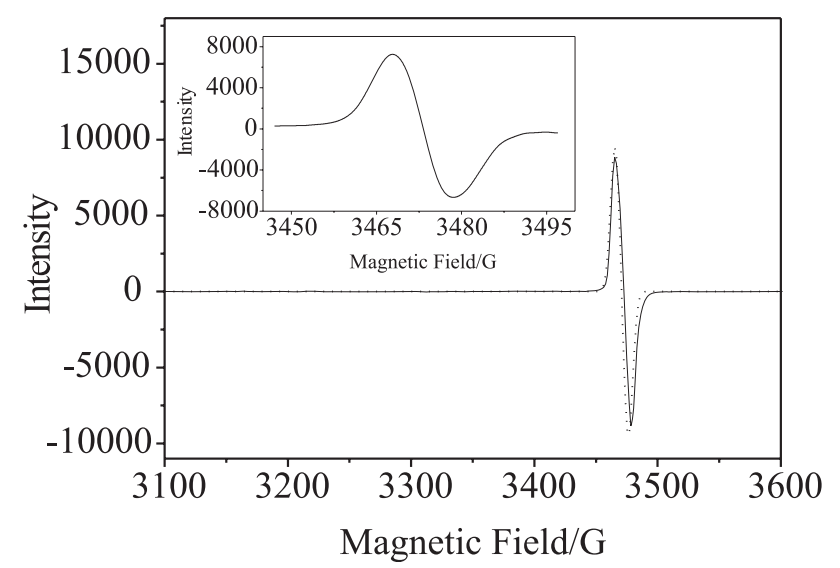

Figure 8. X-band EPR spectrum of [2: $]^{2+}$ : experimental spectrum ( $\left.\cdots\right)$ and simulated spectrum ${ }^{46}$ (一). Conditions: $\mathrm{CH}_{2} \mathrm{Cl}_{2}\left(0.1 \mathrm{~mol} \mathrm{dm}^{-3}\left[(\mathrm{TBA}) \mathrm{PF}_{6}\right]\right)$ at $298 \mathrm{~K}$. Inset: spectrum of [3] $]^{2+}$ under the same experimental conditions employed for $\left[2^{2}\right]^{2+}$.

change was observed concerning the EPR spectrum of complex 4 . For $\left[\mathrm{Fe}\left(\mathrm{L}^{\circ}\right)\right]^{2+}$ a $\mathrm{S}=2$ ground state is expected, ${ }^{6}$ but this has not yet been proven experimentally. 
The trication $\left[\mathrm{M}^{\mathrm{III}}\left(\mathrm{L}^{*}\right)\right]^{3+}$ species for all complexes are unstable under the conditions employed in our experiments ( $298 \mathrm{~K})$. This was also confirmed through the coulometric experiments.

\section{Conclusions}

In this study, $\mathrm{LM}^{\mathrm{III}}$ complexes $(\mathrm{M}=\mathrm{Mn}, \mathrm{Ga}, \mathrm{In}, \mathrm{Fe})$ based on a derivative of the well-known pro-ligand $\mathrm{H}_{2}$ bbpen ( $\left\{N, N^{\prime}, N, N^{\prime}\right.$-Bis[(2-hydroxybenzyl) (2-pyridylmethyl)]ethylenediamine \}) were synthesized. All of the available electrochemical and spectroscopic data suggest that the oxidized forms of the complexes contain coordinated phenoxyl radicals. In no instance has a metalcentered oxidation been observed. The results for the manganese complex differed from those for the other complexes, the oxidized species clearly containing a manganese(IV) ion. This manganese complex undergoes metal- and ligand-centered redox processes, which were elucidated by spectroelectrochemistry and EPR spectroscopy: a phenoxyl radical- $\mathrm{Mn}^{\mathrm{IV}}$ complex is accessible. These $\mathrm{M}^{\mathrm{III}}$-phenoxyl complexes represent additional models for establishing some structural properties, along with the stability and reactivity, of relevant phenoxyl radical species. Further structural and physicochemical studies, involving the synthesis of mononuclear $\mathrm{M}^{\mathrm{III}}=\mathrm{Ga}, \mathrm{In}, \mathrm{Fe}, \mathrm{Mn}$ complexes with suitable pentadentate ligands derived from $\mathrm{N}$-methyl-1,3propanediamine (a labile coordination site for the interaction with alcohol-substrates should be available), are currently underway and will be the subject of future reports.

\section{Acknowledgments}

This research was supported by grants from CNPq, PRONEX and FINEP.

\section{Supplementary Information}

The ${ }^{1} \mathrm{H}$ NMR spectra of compounds $\mathbf{2}$ and $\mathbf{3}$, the squarewave voltammogram and the X-band EPR spectrum of complex $\mathbf{4}$ are available free of charge at http:// jbcs.sbq.org.br, as a PDF file.

The crystallographic data (atomic coordinates and equivalent isotropic displacement parameters, calculated hydrogen atom parameters, anisotropic thermal parameters and bond lengths and angles) have been deposited at the Cambridge Crystallographic Data Centre (deposition numbers CCDC 297919 and CCDC 297920). Copies of this information may be obtained free of charge from:
CCDC, 12 Union Road, Cambridge, CB2 1EZ, UK (Fax: +44-1223-336-033; e-mail: deposit@ccdc.cam.ac.uk or http://www.ccdc.cam.ac.uk).

\section{References}

1. Chaudhuri, P.; Wieghardt, K. In Progress in Inorganic Chemistry; Karlin, K. D., ed., John Wiley \& Sons Inc.: New York, 2001, vol. 50, p. 151 and references therein.

2. Jazdzewski, B. A.; Tolman, W. B.; Coord. Chem. Rev. 2000, 200, 633 and references therein.

3. Itoh, S.; Taki, M.; Fukuzumi, S.; Coord. Chem. Rev. 2000, 198, 3 and references therein.

4. Whittaker, J.W.; Chem. Rev. 2003, 103, 2347 and references therein.

5. Borman, C. D.; Saysell, C. G.; Sokolowski, A.; Twitchett, M. B.; Wright, C.; Sykes, A. G.; Coord .Chem. Rev. 1999, 192, 771 and references therein.

6. Adam, B.; Bill, E.; Bothe, E.; Goerdt, B.; Haselhorst, G.; Hildenbrand, K.; Sokolowski, A.; Steenken, S.; Weyhermüller, T.; Wieghardt, K.; Chem.-Eur. J. 1997, 3, 308.

7. Mukherjee, S.; Weyhermüller, T.; Bothe, E.; Wieghardt, K.; Chaudhuri, P.; Dalton Trans. 2004, 22, 3842.

8. Chun, H.; Chaudhuri, P.; Weyhermüller, T.; Wieghardt, K.; Inorg. Chem. 2002, 41, 790.

9. Müller, J.; Kikuchi, A.; Bill, E.; Weyhermüller, T.; Hildebrandt, P.; Moussa, L. O.; Wieghardt, K.; Inorg. Chim. Acta 2000, 297, 265.

10. Kimura, S.; Bill, E.; Bothe, E.; Weyhermüller, T.; Wieghardt, K.; J. Am. Chem. Soc. 2001, 123, 6025.

11. Neves, A.; Erthal, S. M. D.; Vencato, I.; Ceccato, A. S.; Mascarenhas, Y. P.; Nascimento, O. R.; Hörner, M.; Batista, A. A.; Inorg. Chem. 1992, 31, 4749.

12. Neves, A.; Vencato, I.; Erthal, S. M. D.; Inorg. Chim. Acta 1997, 262,77

13. Neves, A.; Ceccato, A. S.; Erthal, S. M. D.; Vencato, I.; Nuber, B.; Weiss, J.; Inorg. Chim. Acta 1991, 187, 119.

14. Neves, A.; Ceccato, A. S.; Vencato, I.; Mascarenhas, Y. P.; Erasmus-Buhr, C.; J. Chem. Soc., Chem. Commun. 1992, 652.

15. Neves, A.; Ceccato, A. S.; Erasmus-Buhr, C.; Gehring, S.; Haase, W.; Paulus, H.; Nascimento, O. R.; Batista, A. A.; J. Chem. Soc., Chem. Commun. 1993, 1782.

16. Wong, E.; Liu, S.; Rettig, S. J.; Orvig, C.; Inorg. Chem. 1995, $34,3057$.

17. Sokolowski, A.; Müller, J.; Weyhermüller, T.; Schnepf, R.; Hildebrandt, P.; Hildenbrand, K.; Bothe, E.; Wieghardt, K.; J. Am. Chem. Soc. 1997, 119, 8889.

18. Gagné, R.R.; Koval, C.A.; Lisensky, G.C.; Inorg. Chem. 1980, 19, 2854.

19. Anjos, A. dos; Bortoluzzi, A. J.; Szpoganicz, B.; Caro, M. S. B.; Friedermann, G. R.; Mangrich, A. S.; Neves, A.; Inorg. 
Chim. Acta 2005, 358, 3106.

20. Enraf-Nonius; CAD-4 EXPRESS Version 5.1/1.2, Enraf-Nonius: Delft, The Netherlands, 1994.

21. Spek, A.L.; HELENA; CAD-4 Data Reduction Program, Univ. of Utrecht: Netherlands, 1996.

22. Spek, A. L.; PLATON Molecular Geometry and Plotting Program, Univ. of Utrecht: Netherlands, 1997; North, A. C. T.; Phillips, D. C.; Mathews, F. S.; Acta Crystallogr. 1968, A24, 351.

23. Altomare, A.; Burla, M.C.; Camalli, M.; Cascarano, G.; Giacovazzo, C.; Guagliardi, A.; Moliterni, A.G.G.; Polidori, G.; Spagna, R.; J. Appl. Cryst. 1999, 32, 115.

24. Sheldrick, G.M.; SHELXL-97 Program for Crystal Structure Refinement; Univ. of Göttingen: Germany, 1997.

25. Geary, W. J.; Coord. Chem. Rev. 1971, 7, 81.

26. Farrugia, L. J.; J. Appl. Crystallogr. 1997, 30, 565.

27. Streetz, B. R.; Day, R. O.; Marianelli, R. S.; Day, V. W.; Inorg. Chem. 1979, 18, 1847.

28. Bertoncello, K.; Fallon, G. D.; Murray, K.; Inorg. Chim. Acta 1990, 174, 57.

29. Oki, A. R.; Hodgson, D. J.; Inorg. Chim. Acta 1990, 170, 65.

30. Li, X.; Pecoraro, V. L.; Inorg. Chem. 1989, 28, 3403.

31. Bhula, R.; Collier, S.; Robinson, W. T.; Weatherburn, D. C.; Inorg. Chem. 1990, 29, 4027.

32. Nakamura, T.; Niwa, K.; Usugi, S.; Asada, H.; Fujiwara, M.; Matsushita, T.; Polyhedron 2001, 20, 191.

33. Palenik, G. J.; Inorg. Chem. 1997, 36, 4888.

34. Bermejo, M. R.; Fondo, M.; Garcia-Deibe, A.; Rey, M.; SanMartin, J.; Sousa, A.; Watkinson, M.; McAuliffe, C. A.; Pritchard, R. G.; Polyhedron 1996, 15, 4185.

35. Liu, S.; Rettig, S. J.; Orvig, C.; Inorg. Chem. 1992, 31, 5400.
36. Liu, S.; Wong, E.; Karunaratne, V.; Rettig, S. J.; Orvig, C.; Inorg. Chem. 1993, 32, 1756.

37. Liu, S.; Wong, E.; Rettig, S. J.; Orvig, C.; Inorg. Chem. 1993, 32, 4268 .

38. Wong, E.; Liu, S.; Lugger, T.; Hahn, F. E.; Orvig, C.; Inorg. Chem. 1995, 34, 93.

39. Kennard, C. H. L.; Inorg. Chim. Acta 1967, 2, 347.

40. Riley, P. E.; Pecoraro, V. L.; Carrano, C. J.; Raymond, K. N.; Inorg. Chem. 1983, 22, 3096.

41. Moore, D. A.; Fanwick, P. E.; Welch, M. J.; Inorg. Chem. 1989, 28, 1504 .

42. Moore, D. A.; Fanwick, P. E.; Welch, M. J.; Inorg. Chem. 1990, $29,672$.

43. Herse, M.; Meier, H.; Zeeh, B.; Spektroskopische Methoden in der Organischen Chemie, $4^{\text {nd }}$ ed., Thieme Inc.: Stuttgart, 1991.

44. Gottlieb, H. E.; Kotlyar, V.; Nudelman, A.; J. Org. Chem. 1997, 62,7512 .

45. Lanznaster, M.; Neves, A.; Bortoluzzi, A. J.; Assumpc, A. M. C.; Vencato, I.; Machado, S. P. Drechsel, S. M.; Inorg. Chem. 2006, 45, 1005.

46. Bruker EPR; WIN-EPR and SimFonia: Post-Processing Program and Simulation Software for PC-Windows or CDROM, version 1.0, 1997.

Received: June 13, 2006

Published on the web: November 10, 2006 


\title{
New Phenoxyl Radical Complexes of Manganese, Gallium, Indium and Iron Based on an $\mathrm{H}_{2}$ bbpen Ligand Derivative
}

\author{
Ademir dos Anjos, ${ }^{a}$ Adailton J. Bortoluzzi, ${ }^{a}$ Miguel S. B. Caro, ${ }^{a}$ Rosely A. Peralta, ${ }^{a}$ \\ Geraldo R. Friedermann, ${ }^{b}$ Antonio S. Mangrich ${ }^{b}$ and Ademir Neves ${ }^{*, a}$ \\ ${ }^{a}$ LABINC, Departamento de Química, Universidade Federal de Santa Catarina, \\ 88040-900 Florianópolis-SC, Brazil \\ ${ }^{b}$ LABEPR, Departamento de Química, Universidade Federal do Paraná, \\ 81531-970 Curitiba-PR, Brazil
}

Table S1. ${ }^{1} \mathrm{H}$ NMR chemical shifts (ppm), assignments and multiplicity for complex $\mathbf{2}$ and $\mathbf{3}$ in $\mathrm{CD}_{3} \mathrm{CN}$

\begin{tabular}{|c|c|c|c|c|c|}
\hline \multicolumn{3}{|c|}{ Complex 2} & \multicolumn{3}{|c|}{ Complex 3} \\
\hline Chem. Shift & Mult. & Assign. & Chem. shift & Mult. & Assign. \\
\hline 8.95 & $\mathrm{~d}\left({ }^{3} J_{\mathrm{H} / \mathrm{H} 5} 5.4 \mathrm{~Hz}\right)$ & $2 \mathrm{H}_{6}$ & 8.94 & $\mathrm{~d}\left({ }^{3} J_{\mathrm{H} 6 / \mathrm{H} 5} 5.2 \mathrm{~Hz}\right)$ & $2 \mathrm{H}_{6}$ \\
\hline 8.05 & $\mathrm{dd}\left({ }^{3} J_{\mathrm{H} 4 / \mathrm{H} 5} 7.9 \mathrm{~Hz},{ }^{3} J_{\mathrm{H} 4 / \mathrm{H} 3} 7.9 \mathrm{~Hz}\right)$ & $2 \mathrm{H}_{4}$ & 7.89 & $\mathrm{dd}\left({ }^{3} J_{\mathrm{H} 4 / \mathrm{H} 5} 7.8 \mathrm{~Hz},{ }^{3} J_{\mathrm{H} 4 / \mathrm{H} 3} 7.8 \mathrm{~Hz}\right)$ & $2 \mathrm{H}_{4}$ \\
\hline 7.56 & $\mathrm{dd}\left({ }^{3} J_{\mathrm{H} 5 / \mathrm{H} 6} 6.3 \mathrm{~Hz},{ }^{3} J_{\mathrm{H} 5 / \mathrm{H} 4} 6.3 \mathrm{~Hz}\right)$ & $2 \mathrm{H}_{5}$ & 7.48 & $\mathrm{dd}\left({ }^{3} J_{\mathrm{H} 5 / \mathrm{H} 6} 6.2 \mathrm{~Hz},{ }^{3} J_{\mathrm{H} 5 / \mathrm{H} 4} 6.2 \mathrm{~Hz}\right)$ & $2 \mathrm{H}_{5}$ \\
\hline 7.40 & $\mathrm{~d}\left({ }^{3} J_{\mathrm{H} 3 / \mathrm{H} 4} 7.9 \mathrm{~Hz}\right)$ & $2 \mathrm{H}_{3}$ & 7.16 & $\mathrm{~d}\left({ }^{3} J_{\mathrm{H} 3 / \mathrm{H} 4} 7.9 \mathrm{~Hz}\right)$ & $2 \mathrm{H}_{3}$ \\
\hline 7.22 & $\mathrm{~d}\left({ }^{4} J_{\mathrm{H} 8 / \mathrm{H} 7} 2.2 \mathrm{~Hz}\right)$ & $2 \mathrm{H}_{8}^{3}$ & $7.10-7.07$ & $\mathrm{~m}$ & $2 \mathrm{H}_{8} 2 \mathrm{H}_{7}$ \\
\hline 6.97 & $\mathrm{~d}\left({ }^{4} J_{\mathrm{H} 7 / \mathrm{H} 8} 2.2 \mathrm{~Hz}\right)$ & $2 \mathrm{H}_{7}^{\circ}$ & 4.47 & $\mathrm{~d}\left({ }^{2} J 18 \mathrm{~Hz}\right)$ & $2 \mathrm{H}_{2 \mathrm{py}}$ \\
\hline 4.57 & $\mathrm{~d}\left({ }^{2} J 19 \mathrm{~Hz}\right)$ & $2 \mathrm{H}_{2 \mathrm{py}}$ & 4.31 & $\mathrm{~d}\left({ }^{2} J 12 \mathrm{~Hz}\right)$ & $2 \mathrm{H}_{2 \mathrm{ph}}{ }^{2 \mathrm{y}}$ \\
\hline 4.27 & $\mathrm{~d}\left({ }^{2} J 19 \mathrm{~Hz}\right)$ & $2 \mathrm{H}_{2}^{\mathrm{py}} \mathrm{py}$ & 4.20 & $\mathrm{~d}\left({ }^{2} J 18 \mathrm{~Hz}\right)$ & $2 \mathrm{H}_{2}^{2}$ \\
\hline 4.02 & $\mathrm{~d}\left({ }^{2} J 13 \mathrm{~Hz}\right)$ & $2 \mathrm{H}_{2 \mathrm{ph}}$ & 3.85 & $\mathrm{~d}\left({ }^{2} J 12 \mathrm{~Hz}\right)$ & $2 \mathrm{H}_{2, \mathrm{ph}}$ \\
\hline 3.85 & $\mathrm{~d}\left({ }^{2} J 13 \mathrm{~Hz}\right)$ & $2 \mathrm{H}_{2, \mathrm{ph}}$ & 3.35 & $\mathrm{~d}\left({ }^{2} J 10.4 \mathrm{~Hz}\right)$ & $2 \mathrm{H}_{1}$ \\
\hline 3.27 & $\mathrm{~d}\left({ }^{2} J 10 \mathrm{~Hz}\right)$ & $2 \mathrm{H}^{2 \mathrm{ph}}$ & 3.15 & $\mathrm{~d}\left({ }^{2} J 10.4 \mathrm{~Hz}\right)$ & $2 \mathrm{H}_{1}$ \\
\hline 2.96 & $\mathrm{~d}\left({ }^{2} J 10 \mathrm{~Hz}\right)$ & $2 \mathrm{H}_{1}$, & 1.36 & $\mathrm{~s}$ & $18 \mathrm{H}_{9}$ \\
\hline
\end{tabular}

*e-mail: ademir@qmc.ufsc.br 

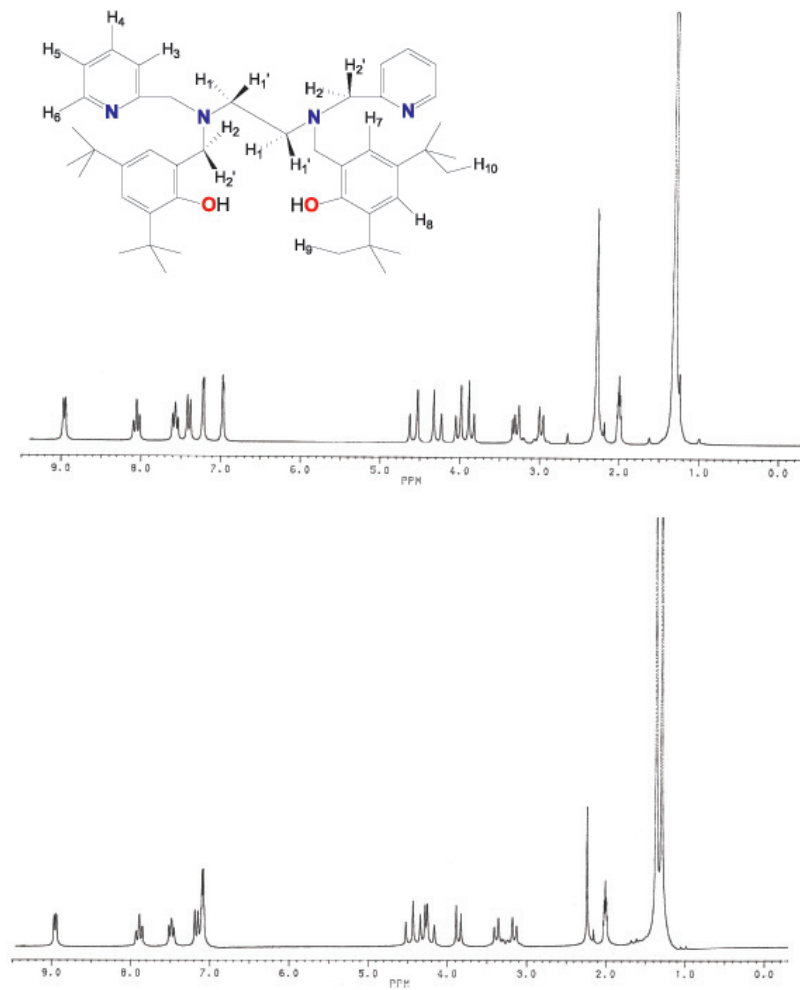

Figure S1. ${ }^{1} \mathrm{H}$ NMR spectra of complex $\mathbf{2}$ (top) and complex $\mathbf{3}$ (bottom) in $\mathrm{CD}_{3} \mathrm{CN}$. Inset: schematic representation for ${ }^{1} \mathrm{H}$ NMR interpretation.

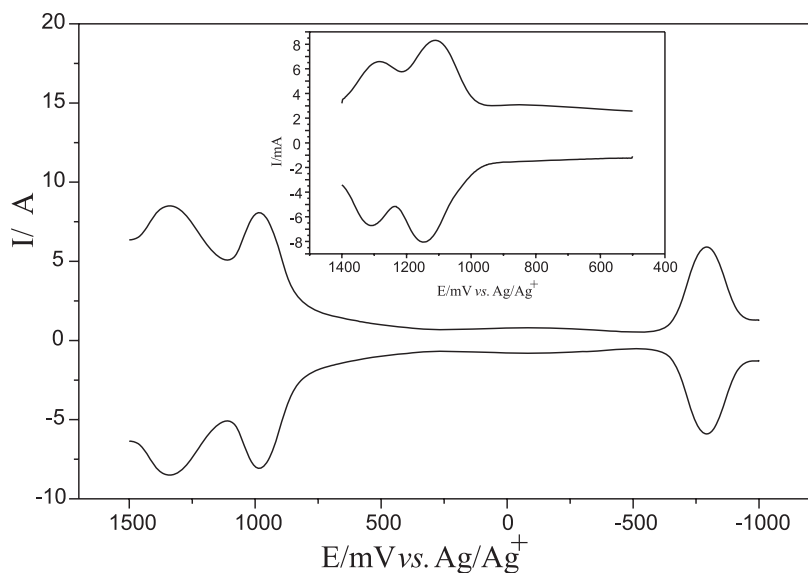

Figure S2. Square wave voltammogram of complex $\mathbf{4}$ in $\mathrm{CH}_{2} \mathrm{Cl}_{2}(0.1$ mol dm$\left.{ }^{-3}\left[(\mathrm{TBA}) \mathrm{PF}_{6}\right]\right)$ : glass carbon working electrode. Conditions: see Table 4. Inset square wave voltammogram of complex $\mathbf{3}$.

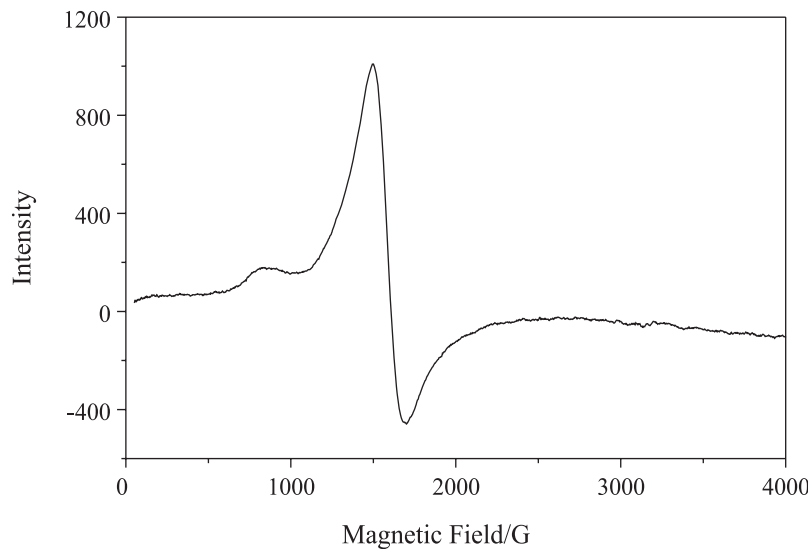

Figure S3. X-band EPR spectrum of complex 4 in $\mathrm{CH}_{2} \mathrm{Cl}_{2}$ at $77 \mathrm{~K}$. 